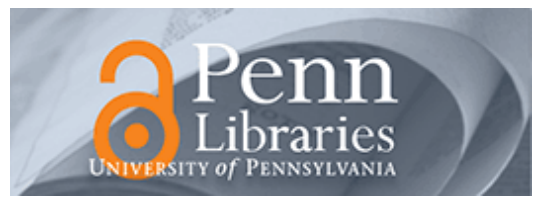

University of Pennsylvania

ScholarlyCommons

Accounting Papers

Wharton Faculty Research

$12-1999$

\title{
The Impact of Cash Flow Volatility on Discretionary Investment and the Costs of Debt and Equity Financing
}

Bernadette A. Minton

Catherine M. Schrand

University of Pennsylvania

Follow this and additional works at: https://repository.upenn.edu/accounting_papers

Part of the Accounting Commons, and the Finance Commons

\section{Recommended Citation}

Minton, B. A., \& Schrand, C. M. (1999). The Impact of Cash Flow Volatility on Discretionary Investment and the Costs of Debt and Equity Financing. Journal of Financial Economics, 54 (3), 423-460.

http://dx.doi.org/10.1016/S0304-405X(99)00042-2

This paper is posted at ScholarlyCommons. https://repository.upenn.edu/accounting_papers/23

For more information, please contact repository@pobox.upenn.edu. 


\title{
The Impact of Cash Flow Volatility on Discretionary Investment and the Costs of Debt and Equity Financing
}

\author{
Abstract \\ increases the costs of doing so.

\section{Keywords} \\ cash flow volatility, investment, cost of equity financing, cost of debt financing \\ Disciplines \\ Accounting | Finance
}

We show that higher cash flow volatility is associated with lower average levels of investment in capital expenditures, R\&D, and advertising. This association suggests that firms do not use external capital markets to fully cover cash flow shortfalls but rather permanently forgo investment. Cash flow volatility also is associated with higher costs of accessing external capital. Moreover, these higher costs, as measured by some proxies, imply a greater sensitivity of investment to cash flow volatility. Thus, cash flow volatility not only increases the likelihood that a firm will need to access capital markets, it also 


\section{The Impact of Cash Flow Volatility on Discretionary Investment and the Costs of Debt and Equity}

\section{Financing}

Bernadette A. Minton ${ }^{*}$ and Catherine Schrand ${ }^{* *}$

Preliminary: Comments welcome

Please do not quote without permission

August, 1998

*Ohio State University. ${ }^{* *}$ University of Pennsylvania. Previous versions of this paper were titled "Costs of Accounting Income versus Cash Flow Volatility." We wish to thank Gordon Bodnar, John Core, Peter Easton, Chris Géczy, Bob Holthausen, Sara Moeller, Tim Opler, Tony Sanders, René Stulz, Ralph Walkling, Franco Wong, an anonymous referee, and workshop participants at the Wharton Corporate Finance seminar, the Ohio State University Finance Seminar, Harvard Financial Decisions and Control Conference, the University of Rochester Ph.D. seminar for helpful comments. Minton thanks the Dice Center for Financial Economics for financial support. Please address comments to either Bernadette A. Minton at Fisher College of Business, The Ohio State University, 1775 College Road, Columbus, OH, 43210-1399, (614) 688-3125, minton.15@osu.edu; or Catherine Schrand at The Wharton School, University of Pennsylvania, 2427 Steinberg Hall-Dietrich Hall, Philadelphia, PA, 19104, (215) 898-6798, schrand@wharton.upenn.edu. 


\title{
The Impact of Cash Flow Volatility on Discretionary Investment and the Costs of Debt and Equity
}

\section{Financing}

\begin{abstract}
We document that cash flow volatility is associated with lower levels of investment in capital expenditures, R\&D, and advertising. Thus, firms do not turn to external capital markets to fully cover cash-flow short falls. Consistent with this conclusion, we document that the sensitivity of investment to cash flow volatility is greater for firms with higher costs of capital market access. In addition, cash flow and earnings volatility are associated with these higher costs. Thus, volatility not only increases the likelihood that a firm will need to access capital markets, it also increases the costs of doing so.

JEL Classification: G31
\end{abstract}

Keywords: Cash flow volatility; earnings volatility; investment; cost of equity financing; cost of debt financing 


\section{The Impact of Cash Flow Volatility on Discretionary Investment and the Costs of Debt and Equity Financing}

\section{Introduction}

"As risk managers, we spend much of our time examining the factors that cause cash flows to fluctuate. This is important work, since low cash flows may throw budgets into disarray, distract managers from productive work, defer capital expenditure or delay debt repayments. By avoiding these deadweight losses, risk managers can rightly claim they add to shareholder value." (See Shimko, 1997.) This paper provides the first direct descriptive evidence that such deadweight losses associated with cash flow volatility exist.

We document that discretionary investment levels are negatively related to cash flow volatility based on an analysis of non-financial firms over the years 1988 to 1995 . Firms with higher levels of cash flow volatility have lower capital expenditures, research and development costs, and advertising expenses. One explanation for this relation is that different levels of investment produce different volatilities due to the nature of the investments. However, we also show that the volatilities of capital expenditures, R\&D costs, and advertising expenses are positively associated with cash flow volatility. We would expect no association between the volatility of investment and cash flow volatility if the documented relation is a simple story about differential payoffs across different types of investments. As further evidence that volatility induces the observed lower investment, we show that firms experiencing cash shortfalls (relative to their own historical experience) have significantly discretionary investment than firms that are not experiencing shortfalls.

These results suggest that firms do not use external debt and equity markets to smooth cash flow volatility. If they did, we would not observe a link between volatility of operating cash flows (before financing) and discretionary investment. Consistent with this interpretation of the results, we show that the sensitivity of investment to volatility is mitigated for large firms and firms with better S\&P bond ratings, greater analyst following, lower total equity price risk, and lower summary measures of firms' costs of accessing equity capital (derived from principal component analysis). These firms, which we claim have lower costs of accessing external capital markets, are able to smooth cash flows through time. In addition, firms that hold higher cash reserves have a lower sensitivity of investment to volatility. 
These results lead to a question of why firms with volatile cash flows do not use external capital markets during periods of low cash realizations to fund investment. As one explanation, we show that the costs of accessing capital markets also are related to the volatility of a firm's cash flows. Thus, we do not conclude that lower investment by firms with volatile cash flows is suboptimal. Rather, the lower investment for these firms is related to lower assessed net present values due to higher costs of funding.

We examine the relation between volatility and our proxies for the costs of accessing external capital markets. In this analysis, we recognize that our proxies are related to assessments of expected future cash flow volatility. However, empirical evidence indicates that earnings levels are a better predictor of future cash flow levels than are historical cash flow levels (e.g., Sloan, 1996). Extending this notion to volatilities, we test whether our proxies for the costs of accessing external capital markets are incrementally associated with cash flow volatility or earnings volatility.

The results indicate that cash flow volatility is relevant to some costs while earnings volatility is relevant to others. Specifically, cash flow volatility and not earnings volatility is significantly related to worse Standard \& Poor's bond ratings and lower analyst following. Earnings volatility and not cash flow volatility is related to higher stock market betas, and lower dividend payout ratios. Cash flow and earnings volatility are both statistically related to total equity price risk. These results have implications for risk-management decisions related to the choice between hedging earnings versus cash flows.

The paper proceeds as follows. Section 2 discusses predictions about the impact of cash flow volatility on discretionary investment. Section 3 describes our metrics for cash flow volatility and the methodology for measuring the association between volatility and investment, and Section 4 reports the results of these tests. In Section 5 , we examine whether the sensitivity of investment to cash flow volatility is mitigated for firms with lower costs of accessing capital markets. Section 6 presents the empirical analyses of the relations between cash flow and earnings volatility and the costs of accessing capital markets. Section 7 provides concluding remarks.

\section{Outline of predictions and relation to prior literature}

In this section, we discuss the impact of cash flow volatility on discretionary investment. We predict that a firm's cash flow volatility over a period will be negatively associated with its average discretionary investment 
during the same period. This prediction relies on two conditions. The first condition is that a firm with higher cash flow volatility is more likely to incur states in which its internal cash levels are insufficient to make investments. The second condition is that covering cash shortfalls is costly so that a firm does not use external capital markets to smooth the effects of volatility.

Our tests for a negative relation between volatility and investment are presented in Sections 4 and 5 . In Section 4, we describe the results of annual cross-sectional regressions of capital expenditures, research and development costs, and advertising expenses as proxies for discretionary investment on cash flow volatility. We also more directly examine whether firms that experience a cash shortfall have lower discretionary investment than firms in an excess cash position. In Section 5, we test whether the negative relation between discretionary investment and volatility is mitigated for firms that have lower costs of accessing external capital markets.

We are not the first to claim that cash flow volatility is costly because it affects investment. The risk management literature has made this claim in the context of explaining hedging activities that reduce cash flow volatility. The risk management theories suggest that the costs of accessing external capital markets to fund investment when internal cash flows are insufficient are greatest for firms with volatile cash flows (Shapiro and Titman (1986), Lessard (1990), Stulz (1990) and Froot, Scharfstein, and Stein (1993)). Consistent with these predictions, empirical research on risk management practices documents that firms that have the greatest expected benefits from reducing volatility are more active in risk management activities (G $\vartheta c z y$, Minton, and Schrand, 1997, Mian, 1996, Nance, Smith, and Smithson, 1993, and Tufano, 1996). The direct evidence in this paper of an association between volatility and discretionary investment complements the findings of these indirect tests.

Our empirical evidence is also related to prior work on the association between liquidity and investment (Fazzari, Hubbard, and Peterson, FHP, 1988 and 1998; Hoshi, Kashyap, and Scharfstein, 1991; Kaplan and Zingales, KZ, 1997; and Lamont, 1997). All of these studies document a positive association between liquidity (as measured by cash flow, cash stock, or the sum of cash flow and cash stock) and investment (as measured by capital expenditures scaled by beginning of period capital). FHP also document that investment-cash flow sensitivities are greater for firms with low dividend payout ratios. They interpret these results as evidence that the sensitivities are proxies for a firm's degree of financing constraint. However, there is some debate about the 
interpretation of the FHP results with the debate focusing on the definition of financing constraints (i.e., KZ, 1997 and FHP, 1988 and 1998).

Our analysis represents a departure from this literature which argues that investment-cash flow sensitivities are proxies for firms' financing constraints. This interpretation requires an assumption that the constraints are sufficient to actually deter investment. If investment is not deterred for financially constrained firms, but is simply more costly, one would observe no difference between the investment-cash flow sensitivities of constrained and unconstrained firms. In contrast to this literature, we claim that a firm's costs of capital market access are related to volatility, and we examine the associations between the various proxies for the costs of financing and volatility.

This analysis of the relation between volatility and the costs of capital market access examines not only cash flow volatility, but also earnings volatility. Anecdotal evidence suggests that firms believe earnings volatility matters. For example, MacDonald (1997) states: "It is no secret on Wall Street that investors place a greater value on companies with steadily rising earnings than they do on companies whose profits move up and down erratically." Likewise, Nocera (1997) suggests that, "The surest way to keep analysts on your side is come up with consistently good earnings..." In addition, a recent survey reports that $49 \%$ of firms indicate that managing fluctuations in cash flows is a primary objective of hedging while $42 \%$ manage accounting earnings (Wharton/CIBC Wood Gundy, 1996). Presumably, these contrasting hedging decisions are both attempts to maximize firm value.

One rational explanation for the focus of investors (equityholders and debtholders) on earnings volatility even though they consume cash flows is that investors use historical earnings volatility to predict future cash flow volatility. At the time that investors price a firm's debt and equity, future cash flow volatility is uncertain. If volatility is correlated with factors that are priced, and if earnings volatility is a good predictor of cash flow volatility, then earnings volatility will be associated with a firm's cost of financing. In Section 6, we test whether it is earnings volatility or cash flow volatility that is more significantly related to a series of proxies for a firm's cost of accessing external debt and equity markets. To the extent that earnings volatility and cash flow volatility are associated with different costs, then which a firm chooses to manage is an important risk management decision. 
Our view that historical volatility is related to equity and debt prices because investors use it to predict future volatility provides another insight related to risk management. This claim suggests that equity and debt prices should depend on the investors' assessments of the expected persistence of the historical volatility into future periods. Prior literature has suggested that equity returns to announcements of unexpected earnings levels are greater if these earnings are more likely to persist into the future (permanent earnings) relative to earnings that represent one-time gains or losses (transitory earnings) (Kormendi and Lipe, 1987; Easton and Zmijewski, 1989; Freeman and Tse, 1992). We extend this notion of persistence in earnings and cash flow levels to the volatility of earnings and cash flows and suggest that the expected persistence of the volatility affects its price. Consequently, how a firm achieves its observed level of historical volatility, and thus its persistence, will affect the price of volatility.

An important research question related to risk management is whether one means of risk management to reduce volatility is equivalent to other means. For example, are the effects of using financial derivatives to reduce short-term volatility similar to the effects of other strategies that might be viewed as longer-term commitments to risk management (such as moving a plant overseas to reduce foreign exchange price risk)? This paper provides a starting point for analyzing the effectiveness of different types of hedging strategies to reduce deadweight losses associated with volatility by documenting (1) the relation between volatility and particular proxies for the costs of accessing debt and equity markets, and (2) whether each proxy is associated with earnings volatility or cash flow volatility. These fundamental observations are necessary to construct tests of whether the source of a firm's volatility is a factor in its costs of accessing capital markets.

\section{Methodology}

\subsection{Measures of volatility}

In this section, we define operating cash flow (OPCF) and our methodology for measuring the volatility in operating cash flow. We measure OPCF before R\&D and advertising expenses. This metric represents the cash flow available for discretionary investment.

We define quarterly operating cash flow as Sales (Compustat data item 2) less Cost of Goods Sold (30) less Selling, General and Administrative Expenses (1) less the change in working capital for the period. Quarterly 
selling, general and administrative expenses exclude one-quarter of annual research and development costs (46) and advertising expenses (45) when those data items are available. Working capital is the sum of the non-missing amounts for accounts receivable, inventory, and other current assets (current assets other than cash and short-term investments) less the sum of the non-missing amounts for accounts payable, income taxes payable, and other current liabilities (current liabilities).

We measure volatility in operating cash flow for all non-financial firms on Compustat as the coefficient of variation (CV) for a firm's quarterly OPCF over the six-year period preceding each of the eight sample years from 1988 through 1995. Thus, for the sample year 1995, the coefficient of variation is calculated over the 24 quarters from the first quarter of 1989 to the fourth fiscal quarter of 1994. A firm is included in the sample for a given year if it has at least 15 non-missing observations during the 24 quarters. The coefficient of variation is the standard deviation of operating cash flow scaled by the absolute value of the mean over the same period. The resulting metric is a unitless measure of variation that has been used in prior studies (Albrecht and Richardson, 1990, and Michelson Jordan-Wagner, and Wootton, 1995).

We adjust the CV of each firm-year observation relative to the median for all sample firms in the same two-digit SIC code for the same sample year. We use industry-adjusted coefficients of variation to control for natural variation across industries in volatility due to the nature of the firms' operations. In addition, industryadjusted variables control for quarterly seasonality in cash flows that may differ across industries. Because of the industry adjusting, we eliminate firms in industries with less than ten firms with available data. We also delete seventy firm-year observations representing twenty-six firms with operating cash flow data that are classified as being in reorganization or liquidation based on their Standard \& Poor's (S\&P) stock ratings.

Our final annual samples consist of between 867 firms (1988) and 1,135 firms (1995) with available operating cash flow data. Table 1 summarizes the number of firms by industry for the 1995 sample. The distributions of firms in other sample years are similar. The sample represents 35 separate two-digit SIC codes. The distribution of the sample firms across industries is consistent with the distribution of firms on Compustat except that our sample excludes firms in the financial services industry.

[INSERT TABLE 1.] 


\subsection{Volatility and discretionary investment}

We examine the impact of volatility on investment using the following model:

$$
\text { INVESTMENT }=\mathrm{a}_{0}+\mathrm{a}_{1} \text { CVCF }+\mathrm{a}_{2} \text { CONTROL }+\varepsilon
$$

INVESTMENT is one of three proxies for discretionary investment: capital expenditures, R\&D costs, and advertising expenses. Capital expenditures (CAPEX) are gross capital expenditures (Compustat data item 90) scaled by the firm's total assets. R\&D costs are measured as the ratio of annual $R \& D$ (Compustat data item 46) to total assets. Advertising expenses are measured as the ratio of annual advertising (Compustat data item 45) to total assets. CVCF is the continuous series of industry-adjusted coefficients of variation in operating cash flows.

We compute average capital expenditures, R\&D costs, and advertising expenses for the same rolling sixyear periods over which we measure volatility. Because the average investment variables are measured contemporaneously with volatility, the results of the regression analyses indicate whether firms with higher volatility during a given period make lower average investments during that same period. We industry-adjust the three proxies for discretionary investment relative to the median for all sample firms in the same two-digit SIC code for the same sample year. Industry-adjusting the proxy variables for investment controls for variation across industries in capital intensity and growth during the sample period.

In addition to cash flow volatility as an explanatory variable, we include two control variables (labeled collectively, CONTROL). The control variables, identified in KZ and FHP, among others, measure growth. FHP identify sales growth as a significant determinant of capital expenditures. We measure sales growth as average annual sales growth for the same rolling six-year periods over which we measure volatility. We use the average market-to-book ratio, measured for the same rolling six-year periods over which we measure volatility, as a proxy for growth opportunities. ${ }^{1}$ FHP and $\mathrm{KZ}$ also include other factors in the regression equations that estimate the determinants of investment. However, it is the growth variables that are consistently significant across various studies. Like the dependent variable and the coefficient of variation, these variables are industry-adjusted.

\footnotetext{
${ }^{1}$ Both FHP and KZ use variants of Tobin's Q as a proxy for growth opportunities. KZ measure Tobin's Q as the ratio of the market value of assets to the book value of assets. FHP measure Tobin's Q using replacement costs.
} 
A potential methodological issue is that the level of a firm's cash flows, rather than their volatility, is the important determinant of discretionary investment, and that there is a relation between volatilities and levels. We use the coefficient of variation to measure volatility which eliminates the possibility for a mechanical relation between volatility and cash flow levels. However, the potential for an economic relation between the CV and the level remains. Table 2 presents descriptive statistics of the industry-adjusted coefficients of variation and levels (scaled by total revenues) of operating cash flow for all sample firms for 1995. Results for other years are similar.

In Panel A, we rank firms into deciles (annually) based on industry-adjusted coefficients of variation in cash flows. Means are reported for decile 1 (the lowest volatility measure), decile 2, decile 3 , the middle four deciles as a group (deciles 4 through 7), decile 8 , decile 9 , and decile 10 (the highest volatility measure). We remove the top ten percent of decile 10 (top one percent of the sample firms). ${ }^{2}$ The increases in the coefficients of variation are non-linear across the deciles. ${ }^{3}$ The industry-adjusted levels of operating cash flow, scaled by revenues, display a negative association with cash flow volatility.

\section{[INSERT TABLE 2.]}

In Panel B, we rank firms into deciles (annually) based on industry-adjusted cash flow levels. A firm is classified as LOW, MEDIUM, or HIGH if it is in the lowest three, middle four or highest three decile rankings, respectively, of the sample firms with respect to its industry-adjusted operating cash flows. As in Panel A, there is an inverse relation between industry-adjusted cash flow volatility and cash flow levels. Panel B also documents that the standard deviations of the coefficients of variation vary across the levels.

Because of the negative relation between cash volatility and cash flow levels documented in Table 2, we include in equation (1) variables to control for the industry-adjusted level of a firm's cash flows (scaled by revenues).

$$
\begin{aligned}
\text { INVESTMENT }= & \mathrm{b}_{0}+\mathrm{b}_{1} \mathrm{LOCF}+\mathrm{b}_{2} \mathrm{HICF}+\mathrm{b}_{3} \mathrm{CVCF}+ \\
& \mathrm{b}_{4} \text { CVCF } * \text { LOCF }+\mathrm{b}_{5} \mathrm{CVCF} * \mathrm{HICF}+\mathrm{b}_{6} \text { CONTROL }+\varepsilon
\end{aligned}
$$

\footnotetext{
${ }^{2}$ Instead of deleting outliers in our analyses, we downweight influential observations and winsorize the data. Specifically, we set all coefficients of variation which are greater than 100 equal to 100 . We chose 100 because, in general. this represents the $99^{\text {th }}$ percentile. After we winsorize the data, the series are more normal with means much closer in value to the medians. ${ }^{3}$ The mean results are driven by some outliers. The medians follow a similar, although less dramatic. pattern.
} 
LOCF (HICF) is an indicator variable equal to one if the firm is in the lowest (highest) three deciles based on its industry-adjusted cash flow. ${ }^{4}$

We estimate equations (1) and (2) annually using ordinary least squares regressions over the eight years from 1988 to 1995 and present the means of the annual estimations. When capital expenditures are the dependent variable, we have only seven years of data from 1989 forward due to missing data in 1988 . To test the hypothesis that the mean coefficient estimate is statistically different from zero, we calculate and report a z-statistic $(z=\bar{t} /(\sigma(t) / \sqrt{(N-1)}))$ where $\mathrm{t}$ and $\sigma(\mathrm{t})$ are the average and standard deviation of the annual t-statistics, respectively, and $\mathrm{N}$ is the number of annual observations. ${ }^{5}$ Influential observations in the annual regressions are downweighted by the method of Welsch (1980).

\section{Results}

\subsection{Regression analysis}

Table 3, Panel A, reports the mean of the annual coefficient estimates from regression equations (1) and (2) using industry-adjusted average capital expenditures, R\&D costs, and advertising expenses as proxies for discretionary investment. We do not present the coefficient estimates on the control variables. Consistent with the results of FHP and KZ, average annual industry-adjusted sales growth has a positive and significant association with investment and average annual industry-adjusted book-to-market ratios have a negative and significant association.

\section{[INSERT TABLE 3.]}

Overall, discretionary investment levels are sensitive to cash flow volatility. In the regressions that include only an intercept and the coefficient of variation (equation (1)), higher industry-adjusted operating cash

\footnotetext{
${ }^{4}$ The specification of equation (2) as a pooled regression with separate parameter estimates across groups is most efficient only if the standard deviations of the independent variables are similar across the groups (Greene. p. 236). Table 2. however. indicates that this is not the case in our sample. In the case of dissimilar variances. the appropriate technique is to estimate equation (1) separately for each group. The results of the analysis using separately specified equations are qualitatively similar to those obtained from the pooled regression.

${ }^{5}$ An alternative test statistic is $z^{*}=1 / \sqrt{N} \sum_{j=1}^{v} t_{j} / \sqrt{k_{j} /\left(k_{j}-2\right)}$ where $t_{j}$ is the t-statistic for year $i$ and $k_{j}$ is the degrees of freedom (see Healy. Kang and Palepu. 1987). $\mathrm{z}^{*}$ assumes the annual parameter estimates are independent and is likely overstated; $\mathrm{z}$ corrects for the potential lack of independence.
} 
flow volatility is associated with significantly lower industry-adjusted capital expenditures, research and development costs, and advertising expenses after controlling for industry-adjusted sales growth and growth opportunities (book-to-market ratios). The results of regressions that include controls for the levels of cash flows (equation (2)) similarly show that capital expenditures and advertising expenses are negatively and significantly related to operating cash flow volatility.

Volatility is not an equally significant determinant of investment across all levels of cash flows. The negative relations between investment and volatility hold only for firms with moderate or high levels of cash flows. As Panel A reports, for low-cash flow firms the negative relations between volatility and capital expenditures ($0.0002)$ and advertising costs $(-0.0012)$ are eliminated (coefficient estimate on CVOPCF*LO $=0.0002$ ) or mitigated (coefficient estimate on $\mathrm{CVOPCF}^{*} \mathrm{LO}=0.0007$ ). Similarly, $\mathrm{R} \& \mathrm{D}$ costs are negatively associated with cash flow volatility only for firms with high levels of cash flows.

The low cash flow firms, however, have lower average industry-adjusted capital expenditures than firms with moderate levels of cash flows. The intercept (0.0022) and the coefficient estimate on the interaction term between the intercept and the indicator variable for the low group $(-0.0043)$ indicate that average capital expenditures as a percentage of total assets are 0.0021 below the industry median for firms with low industryadjusted cash flows. In contrast, firms with high cash flows have average capital expenditures that are 0.0046 above the industry median. These results suggest that cash flow level has a first-order effect on a firm's investment decisions when cash flows are below some threshold. Above the threshold, volatility affects the investment decision, but below the threshold volatility is unimportant.

In interpreting the results of the regressions in Panel A, Table 3, causality is an obvious concern. Our interpretation of these results is that cash flow volatility, on average, leads to lower investment. However, an alternative explanation is that different levels of investment (the dependent variable) produce different volatilities due to the nature of the investments. In order to differentiate these explanations for a relation between investment and volatility, we estimate the association between cash flow volatility and the industry-adjusted volatilities of the three proxy variables for investment. We measure these volatilities over the same time period as that over which we measure the volatility of operating cash flow. If cash flow volatility leads to lower investment, then we expect a positive association between cash flow volatility and the volatility of investment. However, if different levels of 
investment (the dependent variable) produce different volatilities, we expect no association between the volatility of investment and cash flow volatility.

The results of the regressions in which we use the volatilities of our three proxies for discretionary investment as the dependent variables (Panel B of Table 3) indicate that there is a positive association between operating cash flow volatility and the volatility of investment. These results are consistent with our interpretation that higher cash flow volatility leads to lower levels of capital expenditures, R\&D costs, and advertising expenses. The results do not suggest that a firm's investment decisions drive the volatility of its operating cash flows.

Another concern is that the level of a firm's operating cash flow or the volatility of its cash flows could be correlated with firm characteristics such as financial distress or financial constraint, and distressed firms invest less. Thus, the coefficient estimates on the measures of volatility are reflecting the effects of financial distress on investment. In Table 4, we test whether firm characteristics which are proxies for financial distress vary with a firm's cash flow level and its cash flow volatility.

[INSERT TABLE 4.]

The univariate tests in Table 4 indicate that the cash flow level rankings and the CVs are correlated with firm-specific factors that measure distress. Firms with low levels of operating cash flows, which might indicate distress, have statistically and significantly higher industry-adjusted book-to-market ratios, earnings-price ratios, and debt-equity ratios and lower industry-adjusted dividend payout ratios and S\&P bond ratings than firms with high levels of cash flows. In addition, these firms hold higher cash reserves. Likewise, firms with higher coefficients of variation in operating cash flows have lower dividend payout ratios, higher debt-equity ratios, higher sales growth, worse S\&P bond ratings, and hold higher cash reserves.

Given the significant relations in Table 4, we examine whether financially distressed firms are driving the results. We identify and eliminate financially distressed firms in our sample and re-estimate the relation between volatility and investment (equations (1) and (2)). Since there is no consensus on a measure of financial distress, we identify distressed firms using eight different metrics taken from existing studies. We identify a firm as distressed for a sample year if it has: 
1) Speculative grade debt ( $S \& P$ bond ratings greater than or equal to 13 on Compustat).

2) A negative earnings-price ratio.

3) Negative average annual asset growth calculated over the rolling six-year periods preceding each of the sample years.

4) Average total assets (calculated over the rolling six-year periods) that are in the lowest quartile of total assets for all firms in the sample. The annual thresholds range from $\$ 79$ million to $\$ 107$ million.

5) A debt-equity ratio (defined as the book value of long-term debt scaled by the book values of long-term debt plus common equity plus preferred stock) in the sample year that is in the highest quartile of debtequity ratios for all firms in the sample. The annual thresholds range from 0.51 to 0.52 .

6) An average dividend payout ratio (calculated over the rolling six-year periods) less than $10 \%$.

7) Average cash holdings (calculated over the rolling six-year periods) that are in the lowest quartile of cash holdings for all firms in the sample. Cash holdings are defined as short-term cash and cash equivalents scaled by the firm size (SIZE) which is measured as the market value of equity plus the book value of debt. The annual thresholds range from 0.02 to 0.04 .

8) An average interest coverage ratio (defined as average operating income divided by average interest expense) that is in the lowest quartile of interest coverage ratios for all firms in the sample. The annual thresholds range from 1.1 to 1.2 .

Barth, Beaver, and Landsman (BBL, 1997) identify speculative grade S\&P bond ratings, negative earnings-price ratios, low total assets, negative asset growth, and a high ratio of debt-to-total assets as either precursors to bankruptcy or determinants of S\&P bond ratings. BBL also identify negative book-to-market ratios as precursors to bankruptcy, but we already eliminate firms with negative book-to-market ratios from the sample. Fazzari, Hubbard, and Peterson (1988) establish the 10\% cutoff on the dividend payout ratio to identify a firm as financially constrained. The use of the interest coverage ratio as a proxy for financial constraint is consistent with Kaplan and Zingales (1997).

The results for each of the eight reduced samples (not presented) are qualitatively similar to those reported in Table 3. Specifically, we find that higher industry-adjusted operating cash flow volatility is associated with 
significantly lower industry-adjusted capital expenditures, research and development costs, and advertising expenses (after controlling for industry-adjusted sales growth and growth opportunities). Thus, financially distressed firms are not driving the results.

\subsection{Cash shortfall and investment}

The results in the previous section show that firms with more volatile cash flows have lower discretionary investment, on average. The motivation for examining the relation between volatility and investment is that firms with greater volatility are more likely to experience periods of cash-flow shortfalls. As more direct evidence that shortfalls in cash flows are associated with lower investment, we examine the capital expenditures, R\&D and advertising of firms that are experiencing shortfalls.

We define a firm to be in a shortfall position when it is in the lower quartile of the sample firms with respect to its industry-adjusted operating cash flows. As a benchmark against which to evaluate the investments of this group, we examine the investments of firms in the upper quartile which we assume are in an excess cash flow position. As a robustness check of our definition of "cash," we separately identify firms in shortfall positions as those in the lower quartile based on operating cash flows that are not industry-adjusted.

\section{[INSERT TABLE 5.]}

The results in Table 5 are consistent with the previous results and indicate that firms that experience cash shortfalls have lower industry-adjusted levels of discretionary investment (capital expenditures, R\&D costs, and advertising expenses) than those with excess cash flow. The differences are significant at less than the $1 \%$ level in tests including observations from the full sample period. In annual tests, these differences are significant in all sample years for capital expenditures and R\&D. When we do not industry adjust, only capital expenditures and advertising expenses are significantly different.

\section{Cross-sectional variation in the relation between investment and volatility}


Our prediction of a negative relation between volatility and investment assumes that firms face costs of accessing external capital markets to smooth volatility. In this section, we examine whether the costs of accessing capital markets exacerbate the sensitivity of investment to cash flow volatility.

\subsection{Methodology}

The regression equation that we estimate is an augmented version of equation (2) that includes an interaction variable that is the product of the industry-adjusted coefficient of variation of operating cash flow (CVCF) and a proxy for the cost of accessing capital markets (CAPCOST).

$$
\begin{aligned}
\text { INVESTMENT } & =\mathrm{c}_{0}+\mathrm{c}_{1} \mathrm{LOCF}+\mathrm{c}_{2} \mathrm{HICF}+\mathrm{c}_{3} \mathrm{CVCF}+\mathrm{c}_{4} \mathrm{CVCF} * \mathrm{LOCF} \\
& +\mathrm{c}_{5} \mathrm{CVCF} * \mathrm{HICF}+\mathrm{c}_{6} \mathrm{CVCF} * \mathrm{CAPCOST}+\mathrm{c}_{7} \mathrm{CONTROL}+\boldsymbol{\varepsilon}
\end{aligned}
$$

The interaction variable measures whether cross-sectional variation in the costs of accessing capital markets mitigates (or exacerbates) the impact of volatility on investment levels. Because it is difficult to accurately measure the costs of external financing relative to internal financing, we use several proxies for a firm's costs of accessing debt and equity markets. Table 6 describes the detailed calculation of each variable.

\section{[INSERT TABLE 6.]}

We use yield-to-maturity (YTM) and S\&P bond rating (SPBOND) as proxies for a firm's costs of accessing debt markets. The worse (higher) a firm's S\&P bond rating, the higher its debt financing costs as reflected in its yield-to-maturity (Calomiris, Himmelberg, and Wachtel, 1995; Ogden, 1987).

We use four separate proxies for a firm's cost of equity: systematic risk (BETA), total equity price risk $(\sigma R E T)$, analyst following (ANALYST), and dividend payout ratios (DIV). In a Sharpe-Lintner world, crosssectional variation in firms' costs of equity is the direct result of cross-sectional variation in firms' betas. Thus, if the Sharpe-Lintner CAPM is an accurate representation of the world, the higher a firm's stock beta, the higher is its cost of raising equity capital. If, however, the Sharpe-Lintner CAPM is not an accurate representation of the world, then other systematic factors which affect the risk-adjusted discount rate will be subsumed in the residual of 
the market model regression that is used to estimate equity betas. Additionally, changing any of the assumptions underlying the Sharpe-Lintner CAPM model can lead to a role for unsystematic risk in the cost of equity. In this case, the higher the total risk of a firm's stock (systematic risk plus unsystematic risk), the higher is its cost of raising equity capital.

Analyst following, as a proxy for the cost of accessing equity capital, is intended to measure the degree of information asymmetry between the firm and external capital markets. Botosan (1997) summarizes two explanations for a positive association between information asymmetry and a firm's cost of equity. First, greater information reduces transactions costs which creates greater demand for a firm's securities. The greater demand increases liquidity and "liquidity-enhancing policies can increase the value of the firm by reducing its cost of capital." (See Amihud and Mendelson, 1988, p.7.) Second, greater information reduces estimation risk about the value of a firm's equity. Lower estimation risk will reduce the cost of equity if estimation risk is non-diversifiable. We predict that greater analyst following represents a lower cost of accessing equity based on an assumption that analyst following is negatively associated with information asymmetry (Lang and Lundholm, 1996; Brennan and Hughes, 1991).

Finally, we use dividend payout ratios (DIV) as a proxy for a firm's cost of accessing equity because demand for a firm's stock is a function of its dividend policy. Despite the dividend irrelevance proposition in perfect capital markets (Miller and Modigliani, 1961), empirical evidence indicates that capital markets value dividends because of liquidity constraints when equityholders are unable to borrow and lend freely, or because dividends provide a credible signal of management's private information (Asquith and Mullins, 1983; Aharony and Swary, 1980; Lang and Litzenberger, 1989; and Hepworth, 1953). These theories predict that dividends create liquidity, and liquidity is associated with a lower cost of accessing capital markets.

We also use three summary measures of a firm's cost of capital market access. First, we examine the effect of firm size (LOGSIZE, the natural logarithm of SIZE) on the sensitivity of a firm's investment to cash flow volatility. We predict that large firms have lower costs of accessing capital markets than those of small firms. Relative to small firms, large firms have less information asymmetry (Atiase, 1985; Brennan and Hughes, 1991; Collins, Kothari and Rayburn, 1987) and lower costs of issuing securities (Ritter, 1987). We also compute a 
firm's weighted-average cost of capital (WACC). Finally, we use principal components analysis to compute a summary measure of a firm's cost of equity market access.

In the principal components analysis we include the four proxy variables for equity costs (BETA, oRET, DIV, ANALYST) as well as LOGSIZE, average daily trading volume, and average daily bid-ask spread. Based on this analysis, we identify two factors that have eigenvalues greater than one. Together these factors retain approximately $65 \%$ of the variation in the input variables. The variables with significant loadings for the first factor are the natural logarithm of firm size, the standard deviation of returns, bid-ask spreads, and analyst following (all industry-adjusted). The variables with significant loadings for the second factor are industryadjusted beta and industry-adjusted trading volume. We use the factor scores (after oblique rotation) and the standardized industry-adjusted input variables to create two factors that we include in equation (3) as proxies for the cost of accessing equity markets: EQTYCOST1 and EQTYCOST2. ${ }^{6}$

In addition to our proxies for the costs of accessing capital markets, we examine the impact of a firm's holdings of internal cash reserves (CASH) on the sensitivity of its investment to cash flow volatility. Firms with high cash reserves are less likely to need to access external capital markets in periods of shortfalls in current-period cash flows. Clearly, we do not claim that firms with high cash reserves have lower costs of accessing capital. Rather, cash reserves act as a substitute for external capital markets to smooth cash flow volatility.

\section{[INSERT TABLE 7.]}

Table 7 reports the results of these regressions. We report the full set of mean coefficient estimates when S\&P bond ratings are the dependent variable. For the other regressions, the mean coefficient estimates for all variables except the interaction variable are qualitatively similar. Hence, we report only the mean coefficient estimate on the interaction variable to focus on these results. As in Table 3, we do not report the coefficient estimates on the control variables. To test the hypothesis that the mean coefficient estimate is significantly

\footnotetext{
${ }^{6}$ As an alternative to using the factor scores to weight each observation. we also create factors by equally weighting only the input variables with factor scores greater than 0.55 in the initial analysis (after rotation) in all years. This procedure reduces measurement error associated with inputs that have little impact on the factors. The two versions of the first factor have a correlation greater than 0.99 in all years. The two versions of the second factor have a correlation of approximately 0.95 in all years. The results of the analysis with either pair of factors are qualitatively similar.
} 
different from zero, we report a $z$-statistic that corrects for the possibility that the coefficient estimates are not independent. Influential observations in the annual regressions are downweighted by the method of Welsch (1980).

The results in Table 7 indicate that the negative association between operating cash flow volatility and capital expenditures is mitigated for firms with lower costs of accessing external capital markets. We observe positive and significant coefficient estimates on the interaction variables between operating cash flow volatility analyst following (ANALYST) and firm size (SIZE), and negative and significant coefficient estimates on the interaction with S\&P bond ratings (SPBOND), total equity price risk ( $\sigma \mathrm{RET}$ ), and the two factors that summarize a firm's cost of accessing equity markets. If analyst following and firm size are proxies for lower costs of accessing capital markets and S\&P bond ratings and total equity price risk are proxies for higher costs, then these results suggest that less costly access to external capital markets mitigates the sensitivity of discretionary investment to internal cash flow volatility. In addition, firms that hold higher cash reserves, which reduce the need to access external capital markets in periods of cash-flow shortfalls, have a lower sensitivity of investment to cash flow volatility.

\section{Volatility and the cost of accessing capital markets}

In this section, we examine whether volatility affects a firm's cost of accessing capital markets. Our results in the previous section indicate only that these costs exacerbate the sensitivity of a firm's investment to its cash flow volatility. Those tests ignore the underlying source of cross-sectional differences in firms' costs of accessing capital markets. In this section, we investigate whether volatility is a potential source of these differences.

\subsection{Explanations for the relation between volatility and proxies for costs}

There are two important issues related to the discussion of the association between volatility and the expected costs of accessing debt and equity financing. The first issue is whether it is cash flow volatility or accounting earnings volatility that affects the costs of financing. Because equityholders and debtholders consume cash flow, it is reasonable to assume that future cash flow volatility is relevant in valuation. However, it is not 
clear whether historical cash flow volatility or historical earnings volatility is a better predictor of future cash flow volatility. ${ }^{7}$

The second issue is which cash flows or accounting earnings are relevant to the debt and equityholders of a firm. Operating cash flows do not represent the flows on which equityholders and debtholders have a claim. Equityholders have a claim on residual cash flows after debtholders are paid. Debtholders have a claim on cash flows after the results of all firm decisions including investment decisions. We address each of these two issues as we discuss the association between volatility and financing costs.

\section{1.a. Costs of accessing debt}

We predict that a firm's cost of debt financing as measured by its S\&P bond rating and yield-to-maturity is positively related to future cash flow volatility. With interim payments, volatility increases a firm's probability of default, other things equal. For a firm to avoid technical default, cash flows in every period must be sufficient to cover the firm's debt service requirements. Higher cash flow volatility increases the probability that the firm's cash flow realization in any given payment period will not cover its debt service requirements. ${ }^{8}$ The cash flows that are relevant in debt valuation are cash flows after investment.

Although we are not aware of any direct empirical evidence on the association between cash flow volatility and the cost of debt, there is an abundance of indirect empirical evidence on the association between earnings volatility and the cost of debt. Event studies show negative returns at announcements of accounting rule changes that are predicted to increase earnings volatility and indicate that the magnitude of the reaction is positively related to a firm's debt constraints. (See, for example, Collins, Rozeff, and Dhaliwal, 1981, and Lys, 1984.) Other studies show that firms adjust their real activities to avoid volatility, and that the extent of these

\footnotetext{
${ }^{7}$ Whether historical earnings volatility or cash flow volatility is the better predictor of future cash flow volatility is an empirical question. Related empirical evidence suggests that historical accounting earnings, rather than historical cash flows. are a better predictor of future cash flows (Bowen. Burgstahler and Daley. 1986. Sloan. 1996; Finger, 1994; Dechow. 1994). Following Sloan (1996). we perform an analysis of the predictive ability of historical earnings and cash flow volatility for future cash flow volatility. We create ten portfolios of firms based on the volatility of historical cash flows and the volatility of historical earnings. For each portfolio, we measure the mean subsequent cash flow volatility for the firms in the portfolio. The results (not presented) indicate that cash flow volatility is the better predictor of future cash flow volatility over short horizons. However. cash flow volatility and earnings volatility converge to equally good predictors of subsequent cash flow volatility over time horizons of six years. Our results for volatility are not as strong as the results for levels in Sloan (1996). One possible explanation for the difference is that changes in volatility are difficult to identify. This difficulty arises because our annual measures of volatility are calculated over a six-year period. and therefore, each annual observation has five years of overlapping data.

${ }^{8}$ Trueman and Titman (1988) make a similar prediction. They demonstrate that the incentives to smooth income and the costs of volatility are related to industry classification because the probability and costs of bankruptcy vary across industries.
} 
adjustments varies cross-sectionally with firms' debt constraints. (See, for example, Bartov, 1993, and Imhoff and Thomas, 1988). These papers suggest that managers have incentives to smooth income because smoother earnings reduce debtholders' estimates of the volatility of the firm's future cash flows and, consequently, the firm's cost of borrowing.

\section{1.b. Costs of accessing equity}

We predict positive associations between volatility and systematic risk (BETA) and total equity price risk $(\sigma R E T)$ which represent two of our proxies for the costs of accessing equity. If cash flow (or earnings) volatility is correlated with a risk that is priced, then we will observe a positive association between volatility and these market risk measures. Note that we are testing a joint hypothesis that cash flow volatility is correlated with a price-relevant risk and that the market impounds this information in security prices (Beaver, Kettler, and Scholes, 1970). We examine whether systematic and total equity price risk ( $\sigma$ RET) are associated with net cash flows and net income, after both investment and interest charges, because equityholders are the residual claimants to a firm's cash flows and earnings.

We do not make a prediction about the association between volatility and analyst following as a proxy for a firm's cost of accessing equity. Both the academic literature and the popular press suggest that analysts are less likely to follow stocks of firms with more volatile earnings because it makes their job of estimating "normal" earnings more difficult (Beidleman, 1973, Brennan and Hughes, 1991). This argument suggests a negative relation between analyst following and volatility. However, an alternative argument is that analysts add the greatest value, and thus potentially reap the highest compensation, when information asymmetry is greatest (Barth, Kasznik and McNichols, 1998). In this case, assuming a positive association between cash flow (or earnings) volatility and information asymmetry, analysts would prefer to follow high-volatility firms.

A prediction about whether cash flow volatility or earnings volatility is more relevant to analyst following depends on analysts' incentives (Schipper, 1991). The ultimate product of an analyst is a report that makes a stock buy or sell recommendation. One element of the report is the firm's earnings forecast. If analysts value forecast accuracy and it is more difficult to predict earnings for high-volatility firms, then earnings volatility can affect the analyst following decision. In addition, "readers of analyst reports may use forecast accuracy as a 
quantitative measure of the quality of the overall report; this effect will create a preference for accuracy..."

(Schipper, 1991). However, the analyst's stock recommendation decision also depends on other factors that can be related to cash flows and not earnings. Thus, cash flow volatility will be an important determinant of analyst following if it affects the analysts' overall ability to make stock buy/sell recommendations.

We predict that dividend payout ratios are negatively associated with volatility. Empirical evidence shows that negative stock price reactions to dividend decreases are larger in magnitude than positive reactions to dividend increases (Aharony and Swary, 1980). This evidence indicates equityholders value stable dividends. If dividend stability is a priority, firms with higher cash flow volatility are forced to maintain lower dividends to avoid the costs associated with cutting a dividend. ${ }^{9}$

\subsection{Methodology}

To examine the association between volatility and the proxies for the costs of accessing capital markets, we perform regression analysis similar to the tests for the association between volatility and investment. The major difference is that we measure the dependent variable at the end of the period over which we measure volatility. For example, we measure volatility over the six-year period 1988 to 1994 and match this volatility metric with the firm's S\&P bond rating for 1995. In contrast, in the tests of discretionary investment, the average investment and volatility are measured over contemporaneous six-year periods.

We measure the dependent variable differently because our predictions differ about how volatility affects investment versus how it affects our proxies for the cost of accessing capital. Contemporaneous measurement of volatility and investment in the discretionary investment tests reflects the prediction that higher cash flow volatility over a period, and consequently more likely realizations of cash shortfalls, is associated with lower investment during that same period. In contrast, in the tests of the association between volatility and the costs of financing, the prediction is that historical volatility is relevant because investors use historical volatility to predict future volatility. In this case, the bond rating in 1995 , for example, reflects the creditor's assessment of future volatility as of 1995 , which is based on historical volatility.

\footnotetext{
${ }^{9}$ Firms can also provide liquidity with stock repurchases or special dividends. These alternatives bias against observing a relation between volatility and dividend payout ratios.
} 
In order to examine the incremental impact of cash flow volatility and earnings volatility on our proxies for the costs of accessing capital markets, we estimate augmented versions of equations (1) and (2). The augmented version of equation (1) includes continuous measures of both earnings and cash flow volatility. The augmented version of equation (2) includes both cash flow and earnings volatility as well as variables to control for the industry-adjusted levels of a firm's cash flows and earnings.

In each regression equation we also include control variables that have been identified in prior literature as determinants of the dependent variable. The control variables are different for each proxy for the costs of accessing capital markets. Because these control variables are not the focus of our analysis, we do not describe them in detail and we do not present the coefficient estimates on these variables with the regression results. Table 8 summarizes the control variables, the predicted signs, and the source that justifies the use of the variable as a control.

\section{[INSERT TABLE 8.]}

The cash flow and earnings metrics in this analysis should represent the cash flow or earnings on which the stakeholder that creates the cost has a claim. In addition to OPCF, we measure the volatility of cash flow after investment but before financing costs (CVCFAI), net cash flow (NETCF), operating income (CVOPINC), and net income (NETINC), calculated as follows:

Calculation of variables:

Operating cash flow (OPCF)

- Depreciation and amortization

$+\quad$ Change in working capital (as defined in Section 3.1)

$=$ Operating income (OPINC)

- Net capital expenditures: ${ }^{10}$

Gross capital expenditures

- Capitalized interest

- After-tax proceeds from sales of PPE
Compustat

Data Item

$\# 5$

\#90

$\# 147 / 4$

$\# 83^{*}(1-\mathrm{TR})$

\footnotetext{
${ }^{10}$ The proceeds from the sale of property. plant, and equipment (PPE). R\&D and advertising are assumed to be zero if these data are missing on Compustat. Gross capital expenditures are missing for interim quarters during the year for some firms. If the fourth quarter accumulated capital expenditures are missing, then the capital expenditures are assumed to be zero for the year.
} 
- Research and development costs \#46/4

- Advertising expenses

$=$ Cash flow after investment $(\mathrm{CFAI})$

- After-tax interest expense

+ After-tax capitalized interest

$\# 22 *(1-\mathrm{TR})$

$\# 147 / 4 *(1-\mathrm{TR})$

$=$ Net cash flow (NETCF)

Net income (NETINC) is Compustat data item 69. ${ }^{11}$ In all calculations, we assume that the tax rate (TR) is equal to $46 \%$ before $1987,38 \%$ in 1987 , and $34 \%$ after 1987 .

The major non-cash items that are included in net income, but are not included in net cash flows, are accrual accounting adjustments and depreciation and amortization. Net income also includes special items (such as restructuring charges), extraordinary items, earnings and gains/losses from discontinued operations, and the effects of changes in accounting principles. The cash flow measures assume that such non-operating items are non-cash, which is always the case for the effects of changes in accounting principles. Some special and extraordinary items and discontinued operations are non-cash items, such as write-downs in the value of existing assets, but some can involve the payment of cash. For these special items, the assumption that they are non-cash is reasonable if the expenditures related to these items are paid over multiple periods subsequent to the period in which the charge is recorded.

\subsection{Results}

Table 9 reports the results of regressions of industry-adjusted proxies for costs of accessing debt and equity markets on industry-adjusted cash flow and earnings volatility and industry-adjusted control variables. As in the investment regressions, we compute the means of the eight annual ordinary least squares regression coefficients for 1988 to 1995 for each dependent variable. (When yield-to-maturity or WACC is the dependent variable, we estimate the coefficient only for 1995). To test the hypothesis that the mean coefficient estimate is

\footnotetext{
${ }^{11}$ The correlation coefficient between the industry-adjusted volatilities of operating cash flow and operating income is 0.22 . The correlation coefficient between the industry-adjusted volatilities of cash flow after investment and operating income is 0.08 . The correlation coefficient between the industry-adjusted volatilities of net cash flow and net income is 0.07 . Thus. multicollinearity is not a specification problem.
} 
significantly different from zero, we report a $\mathrm{z}$-statistic that corrects for the possibility that the coefficient estimates are not independent. Influential observations in the annual regressions are downweighted by the method of Welsch (1980). We do not present the estimates for the control variables. The results are consistent with those of the literature cited in Table 8.

[INSERT TABLE 9.]

The results indicate that cash flow volatility and earnings volatility are associated with the proxies for a firm's cost of accessing external capital markets. In the regressions that exclude the levels of cash flow and earnings, the means of the coefficient estimates on the volatility of cash flow and earnings are both statistically significant in all regressions except when yield-to-maturity and WACC are the dependent variables. However, once we control for the levels of a firm's cash flows and earnings, differences in the effects of cash flow and earnings volatility emerge. Thus, we focus our discussion on the regression results for these estimations and we do not present the regression results for the equations without the levels variables.

As Table 9 reports, only cash flow volatility, and not earnings volatility, is statistically related to S\&P bond ratings and analyst following. The association between S\&P bond ratings and the volatility of cash flow after investment (CVCFAI) is positive and significant. Thus, higher cash flow volatility is related to worse (higher numerical codes) S\&P bond ratings and a higher cost of accessing debt markets. However, CVCFAI is not related to either the yield-to-maturity on a firm's debt or its WACC. One explanation for this combination of results is that we include S\&P bond ratings as a control variable in the regressions of yield-to-maturity and WACC on volatility. Thus, the results indicate that cash flow and earnings volatility do not have an incremental impact on YTM and WACC after taking into account their impact on the firm's debt rating. Given the strong correlation between S\&P bond ratings and volatility, the lack of additional incremental explanatory power is not surprising.

Analyst following also has a significant negative relation to net cash flow volatility but not earnings volatility. This negative association is consistent with the joint claim that analysts are more likely to make erroneous stock buy/sell recommendations when volatility is high and that analysts attempt to reduce this likelihood by not following firms with volatile cash flows. The observation that cash flow volatility, and not 
earnings volatility, is related to analyst following suggests that analysts do not focus on expected earnings forecast precision when deciding to follow a firm.

We also document in Table 9 that earnings volatility, and not cash flow volatility, is significantly associated with higher stock market betas and lower dividend payout ratios, both of which represent a higher cost of accessing equity capital. ${ }^{12}$ The regression results for beta suggest that earnings volatility is correlated with a risk that is priced, and that the market assesses at least part of this operating risk as systematic. Moreover, the significance of earnings volatility rather than cash flow volatility indicates that the market assesses that earnings volatility is the better measure of the priced risk. The observation that dividend payout ratios are negatively associated with earnings volatility rather than cash flow volatility is consistent with the observation that dividend restrictions in bond covenants are frequently based on accounting earnings realizations (Smith and Warner, 1979).

Finally, Table 9 reports that cash flow and earnings volatility are both statistically related to total equity price risk (as measured by the standard deviation of returns). Taken together with the observation that only net earnings volatility affects beta, this result suggests that net cash flow volatility affects the costs of equity through its association with systematic factors that are not captured by beta or unsystematic risk.

Finally, conditional on the level of a firm's net cash flows or income, volatility appears to have a secondorder effect on analyst following, equity betas, total equity price risk, and dividend payout ratios. In particular, the analyst following of firms with high levels of cash flows is significantly and positively associated with net cash flow volatility. (The coefficient estimate on CVCF is -0.0237 and the coefficient estimate on CVCF*HICF is 0.2747.) This result is consistent with the proposition that analysts can earn rents by following firms where there is a greater demand for information, but only for firms with high levels of net cash flow.

In the case of betas, standard deviations of returns ( $\sigma$ RET), and dividend payout ratios, it is the firms with low net income levels (or cash flow levels for $\sigma$ RET), that are distinguished from firms with either moderate or high levels. Specifically, for low-level firms, the association between volatility and each of these proxies is not statistically different from zero. However, the intercepts indicate that these firms have higher equity betas, higher equity price risk, and lower dividend payout ratios, on average. Thus, similar to the results about the relation

\footnotetext{
${ }^{12}$ We also estimate these regressions using only cash flow volatility and the levels of a firm's cash flows. These regressions indicate that cash flow volatility is not statistically related to stock market betas and is statistically negatively related to dividend payout ratios.
} 
between volatility and discretionary investment, volatility only affects a firm's costs of accessing equity capital above some threshold level. Below this threshold, volatility is unimportant.

In sum, the results in Table 9 support the proposition that volatility increases a firm's costs of accessing external capital to cover cash shortfalls. If financially constrained firms maintain investment but at this higher cost of funding it, we will observe differences in the net returns on investment. We will not, however, observe that more financially constrained firms have lower investment cash flow sensitivities unless the costs are sufficiently high to deter investment. Thus, this evidence offers a potential explanation for the mixed results about whether investment-cash flow sensitivities are good proxies for financing constraints (FHP, 1988 and 1998 and KZ, 1997).

\section{Summary and conclusions}

In this paper, we provide direct evidence that cash flow volatility is associated with lower levels of investment in discretionary items including capital expenditures, research and development costs, and advertising expenses. The sensitivity of investment to cash flow volatility is reduced, but not eliminated, for firms that hold higher buffer stocks of cash and for firms with lower costs of accessing external capital markets.

Moreover, volatility increases the costs of accessing external capital markets that can be used to smooth internal cash flow volatility. In the examination of the impact of volatility on proxies for the costs of capital market access, we consider not only cash flow volatility but also earnings volatility. S\&P bond ratings and analyst following are related to cash flow volatility but not earnings volatility. In contrast, beta and dividend payout ratios are related to earnings volatility but not cash flow volatility. Total equity price risk is related to both. The relative importance of earnings volatility to beta, total equity price risk, and dividend payout ratios suggests that equityholders view historical earnings volatility as a good predictor of future cash flow volatility.

These results have several important implications for risk mangers. First, the results indicate that hedging cash flow volatility and earnings volatility will accomplish different objectives. Hedging cash flow volatility will reduce the likelihood that a firm needs to access external capital to cover shortfalls. However, hedging earnings volatility can reduce the costs of accessing external markets if the firm does require additional capital. Second, our evidence suggests that the expected persistence of the effectiveness of a risk management strategy into future periods is important. The proxies for the costs of accessing capital markets, in theory, are related to assessments 
of expected future cash flow volatility, but our evidence indicates that these proxies are correlated with historical volatility. One interpretation of this result is that historical volatility is used to predict future volatility. If this is the case, then risk management decisions that reduce historical volatility, but which are not expected to have a persistent effect on volatility, will not reduce a firm's costs of accessing external markets. Although this study does not directly address whether the source of a firm's volatility, and thus its persistence, is related to the costs of volatility, our results offer a starting point for contemplation.

Finally, while we document that there are costs associated with a firm's chosen level of volatility, we do not claim that a firm should reduce volatility to zero in order to eliminate these costs. Rather, these costs are one element that a firm should consider in its decisions regarding risk management. The firm must then decide how to trade-off the potential for the costs of volatility in terms of reduced capital expenditures against the costs of managing volatility. 


\section{References}

Aharony, Joseph and Itzhak Swary, 1980, Quarterly dividend and earnings announcements and stockholders' returns: An empirical analysis, Journal of Finance 35,1 - 11 .

Albrecht, David, N. and Frederick M. Richardson, 1990, Income smoothing by economy sector, Journal of Business, Finance and Accounting 17, 713 - 730.

Alford, Andrew W. and James R. Boatsman, 1995, Predicting long-term stock return volatility: Implications for accounting and valuation of equity derivatives, Accounting Review 70, 599-618.

Amihud, Yakov and Haim Mendelson, Liquidity and asset prices: Financial management implications, 1988, Vol 7, Financial Management, 5-15.

Asquith, Paul and David W. Mullins, Jr., 1983, The impact of initiating dividend payments on shareholders' wealth, Journal of Business 56, 77-95.

Atiase, Rowland K., 1985, Predisclosure information, firm capitalization, and security price behavior around earnings announcements, Journal of Accounting Research 23, 21-36.

Balog, Stephen J, 1991, What an analyst wants from you, Financial Executive 7, 47-52.

Banz, Rolf W., 1981, The relationship between return and market value of common stocks, Journal of Financial Economics 9, 3-18.

Barth, Mary E., William H. Beaver, and Wayne R. Landsman, 1997, Relative Valuation Roles of Equity Book Value and Net Income as a Function of Financial Health, Working paper, Stanford University.

Barth, Mary E., Ron Kasznik, and Maureen F. McNichols, 1998, Analyst coverage and intangible assets, Working paper, Stanford University.

Bartov, E., 1993, The timing of asset sales and earnings manipulation, Accounting Review 68, 840-855.

Beaver, William, P. Kettler, and Myron Scholes, 1970, The association between market determined and accounting determined risk measures, Accounting Review, 654-682.

Beidleman, Carl R., 1973, Income smoothing: The role of management, Accounting Review 38, 653-667.

Belsey, D. A., E. Kuh, and R. E. Welsch, 1980, Regression diagnostics: Identifying influential data and potential sources of multicollinearity (John Wiley, New York).

Bhushan, Ravi, 1989, Collection of information about publicly traded firms theory and evidence, Journal of Accounting and Economics 11, 183-206.

Botosan, Christine, 1997, Disclosure level and the cost of equity capital, Accounting Review 72, 323-349.

Bowen, R. M., D. Burgstahler, and L. Daley, 1986, Evidence on the relationships between earnings and various measures of cash flow, Accounting Review 61, 713-725.

Brennan, Michael and Patricia J. Hughes, 1991, Stock prices and the Supply of Information, Journal of Finance 46, 1665-1691.

Calomiris, Charles W., Charles P. Himmelberg, and Paul Wachtel, 1995, Commercial paper, corporate finance, and the business cycle: A microeconomic perspective, Carnegie-Rochester Series on Public Policy 42, 203250 . 
Cheung, Kee H., Thomas H. McInish, Robert A. Wood, and Donald J. Wyhowski, 1995, Production of information asymmetry, and the bid-ask spread: Empirical evidence from analysts' forecasts, Journal of Banking and Finance 19, 1025-1046.

Chung, Yin-Wong and Lilian K. Ng, 1992, Stock price dynamics and firm size: An empirical investigation, Journal of Finance 47, 1985-1997.

Collins, Daniel W., S.P. Kothari, and Judy D. Rayburn, 1987, Firm size and the information content of prices with respect to earnings, Journal of Accounting and Economics 9, 111-138.

Collins, Daniel W., Michael S. Rozeff, and Dan S. Dhaliwal, 1981, The economic determinants of the market reaction to proposed mandatory accounting changes in the oil and gas industry, Journal of Accounting and Economics 3, 37-71.

Dechow, Patricia, 1994, Accounting earnings and cash flows as measures of firm performance: The role of accounting accruals, Journal of Accounting and Economics, 3-42.

Easton, Peter D. and Mark E. Zmijewski, 1989, Cross-sectional variation in the stock market response to accounting earnings announcements, Journal of Accounting Research 11, 117-141.

Ederington, Louis H., Jess B. Yawitz, and Brian E. Roberts, 1987, The information content of bond ratings, Journal of Financial Research 10, 211-226.

Fazzari, Steven M., R. Glenn Hubbard, and Bruce C. Petersen, 1988, Financing constraints and corporate investment, Brookings Papers on Economic Activity, 141-195.

Fazzari, Steven M., R. Glenn Hubbard, and Bruce C. Petersen, 1998, Investment - Cash flow sensitivities are useful: A comment on Kaplan and Zingales, Working paper, Columbia University.

Finger, Catherine, 1994, The ability of earnings to predict future earnings and cash flow, Journal of Accounting Research 32, 210-223.

Freeman, Robert and Senyo Tse, 1992, A nonlinear model of security price responses to unexpected earnings, Journal of Accounting Research 30, 185-209.

Froot, Kenneth, David Scharfstein, and Jeremy Stein, 1993, Risk management: Coordinating investment and financing policies, The Journal of Finance 48, 1629-1658.

G $\vartheta c z y$, Christopher, Bernadette A. Minton, and Catherine Schrand, 1997, Why firms use currency derivatives, Journal of Finance 52, 1323-1354.

Greene, William H., 1993, Econometric Analysis, Second edition, (MacMillan Publishing Co., New York).

Hamada, Robert S., 1972, The effect of the firm's capital structure on the systematic risk of common stocks, Journal of Finance, 435-452.

Healy, Paul M., Sok-Hyon Kang, and Krishna G. Palepu, 1987, The effect of accounting procedure changes on CEOs' cash salary and bonus compensation, Journal of Accounting and Economics 9, 7-34.

Hepworth, Samuel. R., 1953, Smoothing periodic income, Accounting Review 28, 32-39.

Hoshi, Takeo, Anil Kashyap, and David Scharfstein, 1991, Corporate structure, liquidity, and investment: Evidence from Japanese industrial groupings, Quarterly Journal of Economics 56, 33-60.

Imhoff, G., and J. Thomas, 1988, Economic consequences of accounting standards: The lease disclosure rule change, Journal of Accounting and Economics, 277-310. 
Kaplan, Robert S. and Gabriel Urwitz, 1979, Statistical model of bond ratings: A methodological inquiry, Journal of Business 52, 231-261.

Kaplan, Steven N. and Luigi Zingales, 1997, Do investment-cash flow sensitivities provide useful measures of financing constraints?, Quarterly Journal of Economic , 169-215.

Kormendi, Roger and Robert Lipe, 1987, Earnings innovations, earnings persistence, and stock returns, Journal of Business 60, 323-346.

Lamont, Owen, 1997, Cash flow and investment: Evidence from internal capital markets, Journal of Finance 52, 83-111.

Lang, Larry H.P. and Robert H. Litzenberger, 1989, Dividend Announcements: Cash Flow Signalling vs. Free Cash Flow Hypothesis, Journal of Financial Economics 24, 181-191.

Lang and Lundholm, 1996, Corporate disclosure policy and analyst behavior, Accounting Review 71, 467-492.

Lessard, Donald, 1990, Global competition and corporate finance in the 1990s, Journal of Applied Corporate Finance 3, 59-72.

Lys, T., 1984, Mandated accounting changes and debt covenants: The case of oil and gas accounting, Journal of Accounting and Economics, 39-65.

MacDonald, Elizabeth, 1997, FASB rule on the wild sidewalk, Wall Street Journal, Sept. 30, C1.

Mian, Shehzad L., 1996, Evidence on corporate hedging policy, Journal of Financial and Quantitative Analysis 31, 419-439.

Michelson, S. E., J. Jordan-Wagner, and C. W. Wootton, 1995, A market based analysis of income smoothing, Journal of Business Finance and Accounting 22, 1179-1193.

Miller, M.H. and F. Modigliani, 1961, Dividend policy, growth and the valuation of shares, Journal of Finance 34, 411-433.

Nance, Deana R., Clifford W. Smith, Jr., and Charles W. Smithson, 1993, On the determinants of corporate hedging, Journal of Finance 48, 267-284.

Nocera, Joseph, 1997 Who really moves the market? Securities analysts are Wall Street's new stars, Fortune, Oct. $27,90$.

O'Brien, Patricia C. and Ravi Bhushan, 1990, Analyst following and institutional ownership, Journal of Accounting Research 28, 55-76.

Ogden, Joseph P., 1987, Determinants of the ratings and yields on corporate bonds: Tests of the contingent claims model, Journal of Financial Research 10, 329-339.

Ritter, Jay R., 1987, The cost of going public, Journal of Financial Economics 19, 269-281.

Schipper, Katherine, 1991, Commentary on analysts' forecasts, Accounting Horizons 5, 105-121.

Shapiro, Alan, and Sheridan Titman, 1986, An integrated approach to corporate risk management, in Joel Stern and Donald Chew, eds.: The Revolution in Corporate Finance (Basil Blackwell, LTD, England and Basil Blackwell, Inc. Cambridge, MA).

Shimko, David, 1997, Yearnings Per Share, Risk 10, No. 9. 
Sloan, Richard, 1996, Using earnings and free cash flow to evaluate corporate performance, Journal of Applied Corporate Finance, 70-78.

Smith, Clifford W., Jr. and Jerold B. Warner, 1979, On financial contracting: An analysis of bond covenants, Journal of Financial Economics 7, 117-161.

Smith, Clifford W., Jr. and Ross L. Watts, 1992, The investment opportunity set and corporate financing, dividend, and compensation policies, Journal of Financial Economics 32, 263-292.

Stulz, René, 1990, Managerial discretion and optimal financing policies, Journal of Financial Economics 26, 3 28.

Tufano, Peter, 1996, Who manages risk? An empirical examination of risk management practices in the gold mining industry, Journal of Finance 51, 1097-1137.

Trueman, Brett and Titman, Sheridan, 1988, An explanation for accounting income smoothing, Journal of Accounting Research 26 (Supplement), 127-139.

Welsch, R. E., 1980, Regression sensitivity analysis and bounded-influence estimation, in: J. Kmenta and J.B. Ramsay, eds., Evaluation of Econometric Models (Academic Press, New York), 153-167.

Wharton School/CIBC Wood Gundy, 1996, 1995 Survey of derivatives usage by U.S. non-financial firms (University of Pennsylvania). 
Table 1

Summary of firms and industries in the sample.

Sample firms include all firms in two-digit SIC industries in which there are at least ten firms with data available on at least one of the cash flow or accounting earnings metrics that are used in this paper. The number of sample firms reported is the number with data available for operating cash flow (OPCF) for 1995. The firms are on the Compustat quarterly data tapes from 1989 to 1994.

\begin{tabular}{|c|c|c|}
\hline $\begin{array}{c}\text { Industry } \\
\text { Name }\end{array}$ & $\begin{array}{l}\text { Two-digit } \\
\text { SIC Code } \\
\end{array}$ & $\begin{array}{l}\text { Number of } \\
\text { sample firms }\end{array}$ \\
\hline $\begin{array}{l}\text { Metal Mining } \\
\text { Oil and Gas Extraction } \\
\text { Building Construction-General Contractors, Operative Builders } \\
\text { Non-building Construction } \\
\text { Food and Kindred Products } \\
\text { Textile Mill Products } \\
\text { Apparel and Other Finished Products } \\
\text { Lumber and Wood Products, except Furniture } \\
\text { Furniture and Fixtures } \\
\text { Paper and Allied Products } \\
\text { Printing, Publishing and Allied } \\
\text { Chemicals and Allied Products } \\
\text { Petroleum Refining and Related Industries } \\
\text { Rubber and Miscellaneous Plastic Products } \\
\text { Stone, Clay, Glass, and Concrete Products } \\
\text { Primary Metal Industries } \\
\text { Fabricated Metal, except Machinery, Transportation Equipment } \\
\text { Machinery, except Electrical } \\
\text { Electrical, Electrical Machinery, Equipment, Supplies } \\
\text { Transportation Equipment } \\
\text { Measuring Instruments; Photographic Goods; Watches } \\
\text { Miscellaneous Manufacturing Industries } \\
\text { Water Transportation } \\
\text { Transportation by Air } \\
\text { Communication } \\
\text { Electric, Gas, Sanitary Services } \\
\text { Durable Goods-Wholesale } \\
\text { Non-Durable Goods-Wholesale } \\
\text { General Merchandise Stores } \\
\text { Food Stores } \\
\text { Auto Dealers, Gas Stations } \\
\text { Apparel and Accessory Stores } \\
\text { Furniture, Home Furnishings Stores } \\
\text { Eating and Drinking Places } \\
\text { Miscellaneous Retail } \\
\text { Business Services } \\
\text { Motion Pictures } \\
\text { Amusement, except Motion Pictures } \\
\text { Health Services } \\
\text { Environmental Services }\end{array}$ & $\begin{array}{l}10 \\
13 \\
15 \\
16 \\
20 \\
22 \\
23 \\
24 \\
25 \\
26 \\
27 \\
28 \\
29 \\
30 \\
32 \\
33 \\
34 \\
35 \\
36 \\
37 \\
38 \\
39 \\
44 \\
45 \\
48 \\
49 \\
50 \\
51 \\
53 \\
54 \\
55 \\
56 \\
57 \\
58 \\
59 \\
73 \\
78 \\
79 \\
80 \\
87\end{array}$ & 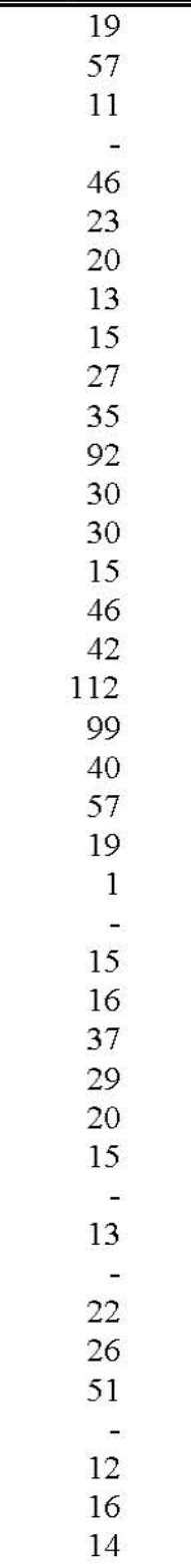 \\
\hline Environmental Services & & 1,135 \\
\hline
\end{tabular}


Table 2

Descriptive statistics of the industry-adjusted coefficients of variation and levels of operating cash flows.

Panel A presents the means, medians, and standard deviations of the industry-adjusted coefficients of variation and the industry-adjusted levels of operating cash flow by decile of firms ranked on the basis of the industry-adjusted coefficient of variation. Panel B presents the means, medians, and standard deviations of the industry-adjusted levels and the industry-adjusted coefficients of variation of operating cash flow by decile of firms ranked on the basis of the level of industry-adjusted operating cash flow. The coefficient of variation is defined as the ratio of the standard deviation to the absolute value of the mean of operating cash flows (OPCF) calculated using quarterly data from 1989 to fiscal-year end 1994. The levels represent average OPCF scaled by average revenues during that period. A firm is classified as LOW, MEDIUM, or HIGH if it is in the lowest three, middle four or highest three decile rankings, respectively, based on the level of its industry-adjusted operating cash flows.

Panel A: Firms ranked based on industry-adjusted coefficients of variation of operating cash flow

\begin{tabular}{|c|c|c|c|c|c|c|c|}
\hline & $\begin{array}{c}\text { Decile } 1 \\
(\mathrm{LOW})\end{array}$ & Decile 2 & Decile 3 & $\begin{array}{c}\text { Deciles } \\
4-7 \\
\end{array}$ & Decile 8 & Decile 9 & $\begin{array}{c}\text { Decile } 10 \\
(\mathrm{HIGH})\end{array}$ \\
\hline ustry-adjusted & of operat & & & & & & \\
\hline Mean & -1.769 & -0.893 & -0.601 & 0.102 & 1.946 & 4.736 & 25.686 \\
\hline Median & -1.665 & -0.894 & -0.594 & 0.000 & 1.971 & 4.366 & 17.587 \\
\hline Std Deviation & 0.610 & 0.092 & 0.077 & 0.423 & 0.489 & 1.453 & 21.005 \\
\hline $\mathrm{N}$ & 80 & 109 & 137 & 500 & 100 & 99 & 98 \\
\hline
\end{tabular}

Industry-adjusted operating cash flow

$\begin{array}{llllllll}\text { Mean } & 0.061 & 0.064 & 0.072 & 0.016 & -0.146 & -0.092 & -0.106 \\ \text { Median } & 0.043 & 0.033 & 0.048 & 0.001 & -0.025 & -0.057 & -0.091 \\ \text { Std Deviation } & 0.189 & 0.110 & 0.104 & 0.101 & 0.851 & 0.213 & 0.082 \\ \text { N } & 80 & 109 & 137 & 500 & 100 & 99 & 98\end{array}$

Panel B: Firms ranked based on level of industry-adjusted operating cash flow

dustry-adjusted CV of operating cash flow

\begin{tabular}{|c|c|c|c|}
\hline & $\begin{array}{c}\text { LOW } \\
\text { (Deciles } 1-3 \text { ) } \\
\end{array}$ & $\begin{array}{c}\text { MEDIUM } \\
(\text { Deciles } 4-7)\end{array}$ & $\begin{array}{c}\text { HIGH } \\
\text { Deciles }(8-10)\end{array}$ \\
\hline \multicolumn{4}{|c|}{ Industry-adjusted operating cash flow } \\
\hline Mean & -0.140 & 0.001 & 0.126 \\
\hline Median & -0.067 & 0.000 & 0.096 \\
\hline Std Deviation & 0.472 & 0.018 & 0.092 \\
\hline $\mathrm{N}$ & 351 & 468 & 351 \\
\hline \multicolumn{4}{|c|}{ Industry-adjusted CV of operating cash flow } \\
\hline Mean & 8.158 & 0.887 & -0.409 \\
\hline Median & 2.524 & -0.090 & -0.483 \\
\hline Std Deviation & 15.704 & 5.660 & 0.955 \\
\hline $\mathrm{N}$ & 337 & 448 & 339 \\
\hline
\end{tabular}


Table 3

Means of annual regressions of proxies for discretionary investment on cash flow volatility.

Means of annual regressions of industry-adjusted capital expenditures, research and development (R\&D) costs, and advertising expense (proxy variables for discretionary investment), on industry-adjusted operating cash flow volatility (CVOPCF). LO and $\mathrm{HI}$ are indicator variables equal to one if a firm is in the lowest or highest three decile rankings, respectively, based on the level of its industry-adjusted operating cash flows. Operating cash flow is sales - cost of goods sold - selling, general and administrative expenses (excluding R\&D and advertising) - the change in working capital (OPCF). For each equation, means of the annual least squares values for each coefficient $\left(\bar{\alpha}_{i t}\right)$ are presented. z-statistics to test the hypothesis that $E(\bar{\alpha})$ are shown in parentheses. Influential observations in the annual estimations are downweighted by the method of Welsch (1980). Regressions for capital expenditures (R\&D and advertising ) are estimated annually over the seven (eight) years from 1989-1995 (19881995). Coefficient estimates on control variables included in the regressions (industry-adjusted book-to-market ratio and industry-adjusted sales growth) are not presented.

\begin{tabular}{|c|c|c|c|c|c|c|c|c|}
\hline \multicolumn{9}{|c|}{ Panel A: Regressions of investment levels on operating cash flow volatility } \\
\hline \multirow{4}{*}{$\begin{array}{l}\text { Dependent variable: } \\
\text { Capital expenditures }\end{array}$} & \multicolumn{3}{|c|}{ Intercept $*$} & \multirow{3}{*}{$\begin{array}{c}\mathrm{CV} \\
\mathrm{OPCF} \\
-0.0002 \\
(-23.267)\end{array}$} & \multicolumn{2}{|c|}{$\mathrm{CVOPCF}^{*}$} & \multirow{2}{*}{\multicolumn{2}{|c|}{ Range of Adj. $R^{2} s$}} \\
\hline & \multirow{2}{*}{$\begin{array}{c}\text { Intercept } \\
0.0027 \\
(28.366)\end{array}$} & \multirow[t]{2}{*}{$\mathrm{LO}$} & $\mathrm{HI}$ & & \multirow[t]{2}{*}{$\mathrm{LO}$} & \multirow[t]{2}{*}{$\mathrm{HI}$} & & \\
\hline & & & & & & & $2.77 \%$ & $5.52 \%$ \\
\hline & $\begin{array}{r}0.0022 \\
(12.035) \\
\end{array}$ & $\begin{array}{l}-0.0043 \\
(-8.236)\end{array}$ & $\begin{array}{r}0.0024 \\
(12.014) \\
\end{array}$ & $\begin{array}{l}-0.0002 \\
(-7.969) \\
\end{array}$ & $\begin{array}{r}0.0002 \\
(5.290) \\
\end{array}$ & $\begin{array}{l}-0.0016 \\
(-4.140) \\
\end{array}$ & $9.26 \%$ & $12.96 \%$ \\
\hline \multirow[t]{2}{*}{ R\&D costs } & $\begin{array}{c}0.0061 \\
(8.943)\end{array}$ & & & $\begin{array}{l}-0.0005 \\
(-7.116)\end{array}$ & & & $-0.14 \%$ & $3.12 \%$ \\
\hline & $\begin{array}{r}0.0019 \\
(3.453) \\
\end{array}$ & $\begin{array}{l}-0.0019 \\
(-1.079) \\
\end{array}$ & $\begin{array}{r}0.0085 \\
(6.061) \\
\end{array}$ & $\begin{array}{c}0.00002 \\
(-0.081) \\
\end{array}$ & $\begin{array}{l}-0.0002 \\
(-0.414) \\
\end{array}$ & $\begin{array}{l}-0.0045 \\
(-4.211) \\
\end{array}$ & $2.00 \%$ & $6.71 \%$ \\
\hline \multirow[t]{2}{*}{ Advertising expenses } & $\begin{array}{c}0.0105 \\
(27.752)\end{array}$ & & & $\begin{array}{l}-0.0007 \\
(-6.566)\end{array}$ & & & $-0.56 \%$ & $2.22 \%$ \\
\hline & $\begin{array}{r}0.0049 \\
(8.490) \\
\end{array}$ & $\begin{array}{r}0.0020 \\
(1.347) \\
\end{array}$ & $\begin{array}{r}0.0092 \\
(5.364) \\
\end{array}$ & $\begin{array}{l}-0.0012 \\
(-5.872) \\
\end{array}$ & $\begin{array}{r}0.0007 \\
(2.475) \\
\end{array}$ & $\begin{array}{l}-0.0034 \\
(-5.509) \\
\end{array}$ & $0.67 \%$ & $3.09 \%$ \\
\hline \multicolumn{9}{|c|}{ Panel B: Regressions of investment volatility on operating cash flow volatility } \\
\hline \multirow[t]{2}{*}{ Dependent variable: } & & \multicolumn{2}{|c|}{ Intercept $*$} & $\mathrm{CV}$ & \multicolumn{2}{|c|}{$\mathrm{CVOPCF}^{*}$} & & \\
\hline & Intercept & $\mathrm{LO}$ & $\mathrm{HI}$ & $\mathrm{OPCF}$ & $\mathrm{LO}$ & $\mathrm{HI}$ & Range c & Adj. $R^{2} s$ \\
\hline \multirow[t]{2}{*}{$\begin{array}{l}\text { Capital expenditure } \\
\text { volatility }\end{array}$} & $\begin{array}{c}0.0702 \\
(16.159)\end{array}$ & & & $\begin{array}{c}0.0134 \\
(7.692)\end{array}$ & & & $0.63 \%$ & $7.11 \%$ \\
\hline & $\begin{array}{r}0.0668 \\
(7.186) \\
\end{array}$ & $\begin{array}{r}0.1307 \\
(4.567)\end{array}$ & $\begin{array}{l}-0.0272 \\
(-2.471)\end{array}$ & $\begin{array}{c}0.0182 \\
(3.752)\end{array}$ & $\begin{array}{l}-0.0106 \\
(-1.177)\end{array}$ & $\begin{array}{c}0.0510 \\
(3.311)\end{array}$ & $0.64 \%$ & $9.33 \%$ \\
\hline \multirow[t]{2}{*}{ R\&D cost volatility } & $\begin{array}{c}0.0162 \\
(6.601)\end{array}$ & & & $\begin{array}{c}0.0070 \\
(13.592)\end{array}$ & & & $5.08 \%$ & $13.53 \%$ \\
\hline & $\begin{array}{r}0.0204 \\
(4.426) \\
\end{array}$ & $\begin{array}{r}0.0565 \\
(4.401) \\
\end{array}$ & $\begin{array}{l}-0.0060 \\
(-0.189) \\
\end{array}$ & $\begin{array}{r}0.0236 \\
(4.457) \\
\end{array}$ & $\begin{array}{l}-0.0219 \\
(-3.849) \\
\end{array}$ & $\begin{array}{r}0.0335 \\
(3.852) \\
\end{array}$ & $10.79 \%$ & $25.05 \%$ \\
\hline \multirow[t]{2}{*}{$\begin{array}{l}\text { Advertising expense } \\
\text { volatility }\end{array}$} & $\begin{array}{c}0.0119 \\
(4.202)\end{array}$ & & & $\begin{array}{c}0.0052 \\
(12.982)\end{array}$ & & & $4.68 \%$ & $11.15 \%$ \\
\hline & $\begin{array}{r}0.0155 \\
(2.579) \\
\end{array}$ & $\begin{array}{r}0.0139 \\
(1.705) \\
\end{array}$ & $\begin{array}{c}0.0076 \\
(0.869) \\
\end{array}$ & $\begin{array}{c}0.0111 \\
(4.805) \\
\end{array}$ & $\begin{array}{l}-0.0083 \\
(-2.354) \\
\end{array}$ & $\begin{array}{r}0.0230 \\
(4.203) \\
\end{array}$ & $5.58 \%$ & $13.19 \%$ \\
\hline
\end{tabular}


Table 4

Univariate tests of firm characteristics.

Univariate tests of firm characteristics by level of industry-adjusted operating cash flows and by industry-adjusted coefficient of variation of operating cash flows. In Panel A, a firm is classified as Low, Medium, or High if it is in the lowest three, middle four or highest three decile rankings, respectively, based on the level of its industryadjusted average operating cash flows. In Panel B, a firm is classified as Low, Medium, or High if it is in the lowest three, middle four or highest three decile rankings, respectively, based on the of its industry-adjusted coefficient of variation of operating cash flows.

\begin{tabular}{|c|c|c|c|c|c|c|c|}
\hline \multirow{2}{*}{$\begin{array}{l}\text { Industry-adjusted } \\
\text { firm characteristic }\end{array}$} & \multicolumn{2}{|c|}{ Low } & \multicolumn{2}{|c|}{ Medium } & \multicolumn{2}{|c|}{ High } & \multirow{2}{*}{$\begin{array}{l}\text { High vs. Low } \\
\text { t-statistic }\end{array}$} \\
\hline & $\mathrm{N}$ & Mean & $\mathrm{N}$ & Mean & $\mathrm{N}$ & Mean & \\
\hline Book-market ratio & 333 & 0.0707 & 444 & 0.0419 & 338 & 0.0083 & -3.728 \\
\hline Cash reserves & 347 & 0.0381 & 467 & 0.0224 & 348 & 0.0196 & -3.167 \\
\hline Dividend payout ratio & 327 & 0.0319 & 436 & 0.1298 & 314 & 0.1648 & 7.181 \\
\hline Debt-equity ratio & 354 & 0.0513 & 470 & 0.0457 & 349 & 0.0009 & -3.590 \\
\hline Earnings-price ratio & 258 & 0.0196 & 398 & 0.0144 & 308 & 0.0088 & -2.706 \\
\hline $\log ($ firm size $)$ & 354 & -0.9746 & 470 & 0.0826 & 350 & 0.7913 & 13.256 \\
\hline Sales growth & 347 & 0.0202 & 469 & 0.0115 & 349 & 0.0128 & -1.509 \\
\hline $\mathrm{S} \& \mathrm{P}$ bond rating & 98 & 1.6224 & 196 & 0.1964 & 170 & -1.1500 & -7.135 \\
\hline \multicolumn{3}{|c|}{$\begin{array}{l}\text { Panel B: Firms ranked based on industry-adju } \\
\text { Industry-adjusted }\end{array}$} & \multicolumn{2}{|c|}{ Medium } & \multicolumn{2}{|c|}{ High } & High vs. Low \\
\hline firm characteristic & $\mathrm{N}$ & Mean & $\mathrm{N}$ & Mean & $\mathrm{N}$ & Mean & t-statistic \\
\hline Book-market ratio & 327 & 0.0372 & 434 & 0.0441 & 311 & 0.0402 & 0.181 \\
\hline Cash reserves & 337 & 0.0155 & 448 & 0.0278 & 332 & 0.0356 & 3.438 \\
\hline Dividend payout ratio & 311 & 0.210 & 405 & 0.1106 & 318 & 0.0019 & -11.273 \\
\hline Debt-equity ratio & 338 & -0.0069 & 451 & 0.0334 & 338 & 0.0821 & 5.980 \\
\hline Earnings-price ratio & 299 & 0.108 & 394 & 0.0153 & 236 & 0.0145 & 0.969 \\
\hline $\log ($ firm size $)$ & 338 & 0.6406 & 451 & 0.1256 & 339 & -0.8519 & -11.018 \\
\hline Sales growth & 336 & 0.0024 & 451 & 0.0118 & 334 & 0.0301 & 5.454 \\
\hline $\mathrm{S} \& \mathrm{P}$ bond rating & 158 & -1.6646 & 187 & 3.2185 & 103 & 2.2184 & 10.507 \\
\hline
\end{tabular}


Table 5

Discretionary investment for firms in a cash shortfall versus cash excess position.

Capital expenditure, R\&D costs, and advertising expense for firms in a cash shortfall versus cash excess position. A firm is in a shortfall (excess) position and classified as Short (High) if it is in the lowest (highest) quartile for industry-adjusted operating cash flow and operating cash flow. Results presented represent the averages across all sample years. t-statistics for the differences in the means of discretionary investment for short and high quartiles are reported in the next to last column. "\# sig years" denotes the number of sample years in annual analysis for which the difference in the means is statistically significant at better than the $10 \%$ significance level. Capital expenditures are analyzed over the seven years from 1989-1995. R\&D and advertising are analyzed over the eight years from 1988-1995.

\begin{tabular}{|c|c|c|c|c|}
\hline & Short & High & t-stat & $\begin{array}{l}\text { \# sig } \\
\text { years }\end{array}$ \\
\hline \multicolumn{5}{|c|}{ Ranked on industry-adjusted operating cash flow } \\
\hline Industry-adjusted capital expenditures & -0.0019 & 0.0056 & 18.713 & 7 \\
\hline Industry-adjusted R\&D costs & 0.0007 & 0.0152 & 10.634 & 8 \\
\hline Industry-adjusted advertising expense & 0.0115 & 0.0223 & 4.757 & 3 \\
\hline \multicolumn{5}{|l|}{ Ranked on operating cash flow } \\
\hline Capital expenditures & 0.0157 & 0.0205 & 12.208 & 7 \\
\hline$R \& D$ costs & 0.0386 & 0.0377 & -0.597 & 1 \\
\hline Advertising expense & 0.0386 & 0.0521 & 6.368 & 4 \\
\hline
\end{tabular}


Table 6

Definitions of variables that proxy for the cost of accessing external capital markets.

\begin{tabular}{|c|c|c|}
\hline Variable & Variable Name & Definition \\
\hline \multicolumn{3}{|c|}{ Cost of accessing debt market: } \\
\hline Yield-to-maturity & YTM & $\begin{array}{l}\text { Weighted-average YTM on long-term debt (excluding convertible debt) using } \\
\text { data from S\&P Bond Guides. Yield-to-maturity is calculated only at calendar } \\
\text { year end } 1995 \text {. }\end{array}$ \\
\hline $\mathrm{S} \& \mathrm{P}$ bond rating & SPBOND & $\begin{array}{l}\text { The average S\&P rating from Compustat (data item 280) and S\&P Bond } \\
\text { Guides. }\end{array}$ \\
\hline \multicolumn{3}{|c|}{ Cost of accessing equity market: } \\
\hline Systematic risk & BETA & The annual beta of common stock obtained from CRSP stock files. \\
\hline $\begin{array}{l}\text { Total equity price } \\
\text { risk }\end{array}$ & ФRET & $\begin{array}{l}\text { The annual standard deviation of daily market returns obtained from CRSP } \\
\text { stock files. }\end{array}$ \\
\hline Analyst following & ANALYST & $\begin{array}{l}\text { The maximum number of analysts making a forecast of earnings during the } \\
\text { sample calendar year from } \mathrm{I} / \mathrm{B} / \mathrm{E} / \mathrm{S} \text {. }\end{array}$ \\
\hline $\begin{array}{l}\text { Dividend payout } \\
\text { ratio }\end{array}$ & DIV & The ratio of cash dividends per share during the fiscal year \\
\hline & & (Compustat data item 26) to earnings before extraordinary items \\
\hline & & per share (Compustat data item 58). \\
\hline \multicolumn{3}{|c|}{ Other costs of accessing capital markets: } \\
\hline $\begin{array}{l}\text { Total firm } \\
\text { capitalization }\end{array}$ & SIZE & $\begin{array}{l}\text { The market value of equity plus the book value of debt plus preferred stock } \\
\text { (Compustat data item 130). The market value of equity is share price times } \\
\text { the number of common shares outstanding (Compustat data item } 199 * \text { data } \\
\text { item 25). The book value of debt is long-term debt plus the current portion of } \\
\text { long-term debt (Compustat data item } 9+\text { data item } 34 \text { ). }\end{array}$ \\
\hline $\begin{array}{l}\text { Internally } \\
\text { available funds }\end{array}$ & $\mathrm{CASH}$ & $\begin{array}{l}\text { Short-term cash and cash equivalents (Compustat data item 1) scaled by } \\
\text { SIZE. }\end{array}$ \\
\hline $\begin{array}{l}\text { Weighted average } \\
\text { cost of capital }\end{array}$ & WACC & $\begin{array}{l}\text { The after-tax YTM times the book value of long-term debt scaled by SIZE } \\
\text { plus the return on equity from CRSP times the market value of equity scaled } \\
\text { by SIZE. }\end{array}$ \\
\hline
\end{tabular}


Table 7

Means of annual regressions of capital expenditures on cash flow volatility and interaction variables that measure the costs of capital market access.

Means of annual regressions of industry-adjusted capital expenditures on industry-adjusted cash flow volatility (CVOPCF) and an interaction variable that is the product of cash flow volatility and a proxy for the cost of access to capital markets. The proxies are S\&P bond ratings (SPBOND), yield-to-maturity (YTM), equity beta (BETA), standard deviation of returns ( logarithm of firm size (SIZE), cash reserves (CASH), weighted average cost of capital (WACC), or two summary factors for the cost of equity from principal components analysis (EQTYCOST1 and EQTYCOST2). All of the proxies are industry-adjusted. The regressions include controls for the industry-adjusted level of a firm's operating cash flows: LO and $\mathrm{HI}$ are indicator variables equal to one if a firm is in the lowest or highest three decile rankings, respectively, based on the level of its industry-adjusted operating cash flows. Operating cash flow is sales - cost of goods sold - selling, general and administrative expenses (excluding R\&D and advertising) - the change in working capital (OPCF). For each equation, the mean of the seven annual least squares values of the coefficient on the interaction variable $\left(\bar{\alpha}_{i t}\right)$ is presented. z-statistics to test the hypothesis that $E(\bar{\alpha})$ are shown in parentheses. Influential observations in the annual estimations are downweighted by the method of Welsch (1980). Coefficient estimates on control variables included in the regressions (industry-adjusted book-to-market ratio and industry-adjusted sales growth) are not presented. We report the full set of mean coefficient estimates when S\&P bond ratings are the dependent variable. For the other regressions, we report only the mean coefficient estimate on the interaction variable to focus on these results.

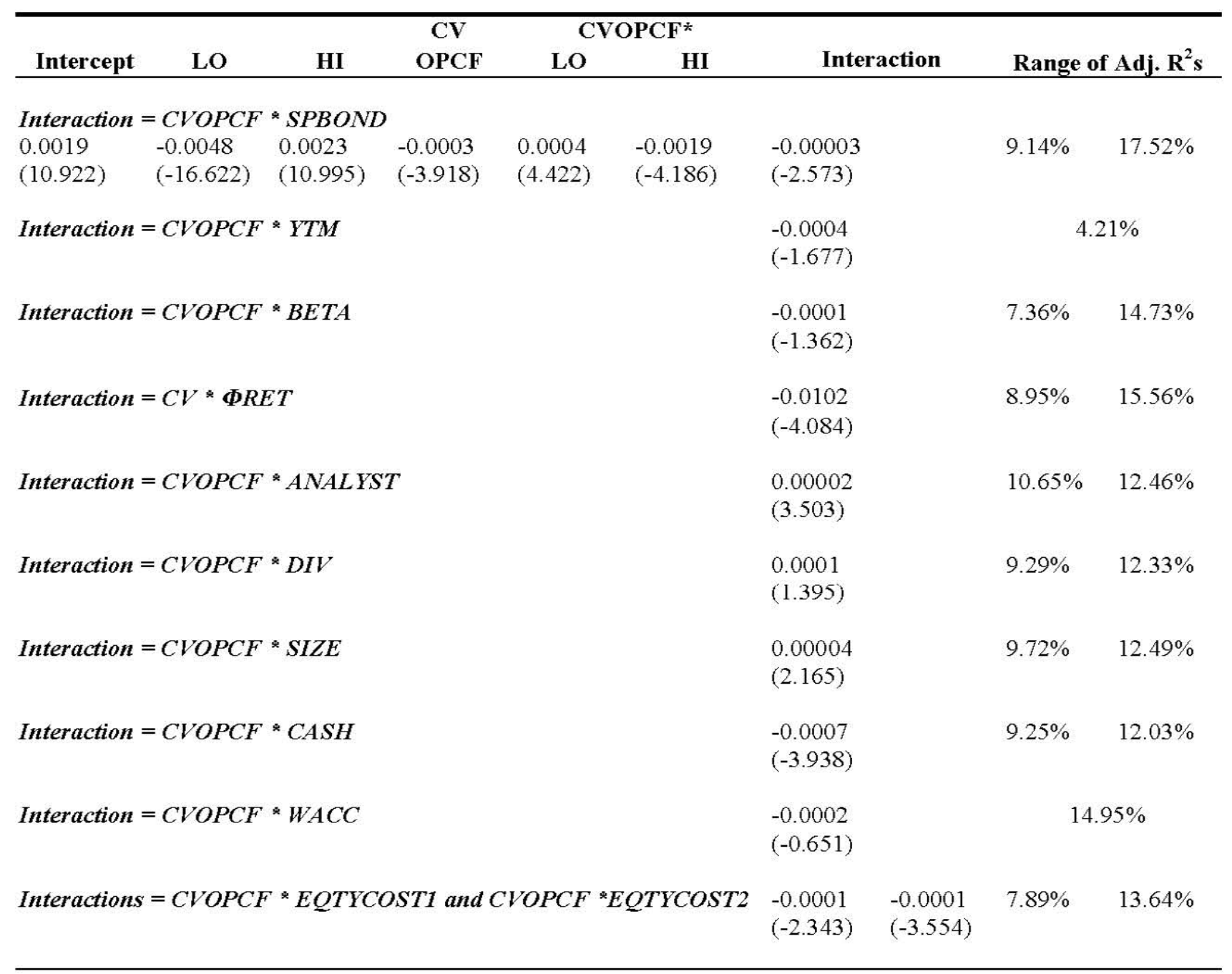


Llers Table 8

Summary of control variables.

Summary of control variables that are used in the regressions which estimate the relation between volatility and the costs of accessing external capital markets. The proxies are $S \& P$ bond ratings, yield-to-maturity, equity beta. standard deviation of returns, dividend payout ratios. and analyst following. "Sign" denotes the predicted sign of the coefficient estimate for the control variable based on extant empirical research. "Cite" refers to the citation(s) for the predicted coefficient estimate.

\begin{tabular}{|c|c|c|c|c|c|c|c|c|c|c|c|c|}
\hline \multirow{3}{*}{ Control Variables } & \multicolumn{4}{|c|}{ Proxies for costs of accessing debt markets } & \multicolumn{8}{|c|}{ Proxies for costs of accessing equity markets } \\
\hline & \multicolumn{2}{|c|}{$\mathrm{S} \& \mathrm{P}$ bond rating } & \multicolumn{2}{|c|}{ Yield-to-maturity } & \multicolumn{2}{|c|}{ Beta } & \multicolumn{2}{|c|}{$\begin{array}{l}\text { Standard deviation of } \\
\text { returns }\end{array}$} & \multicolumn{2}{|c|}{ Dividend payout ratio } & \multicolumn{2}{|c|}{ Analyst following } \\
\hline & Sign & Cite & Sign & Cite & Sign & Cite & Sign & Cite & Sign & Cite & Sign & Cite \\
\hline Firm size & - & Ogden & - & Ogden & - & Banz & - & $\mathrm{AB}$ & + & SW & + & $\begin{array}{l}\text { OB.BH. } \\
\text { Bhushan }\end{array}$ \\
\hline S\&P bond rating & & & + & EYR & & & & & & & & \\
\hline Leverage & + & $\begin{array}{l}\text { KU, } \\
\text { Ogden }\end{array}$ & + & EYR & + & $\begin{array}{l}\text { Hamada.B } \\
\text { KS }\end{array}$ & & & + & SW & & \\
\hline Beta & + & KU & & & & & & & & & & \\
\hline Bid-ask spread & & & & & & & - & $\mathrm{CN}$ & & & + & 13 \\
\hline Trading volume & & & & & & & + & $\mathrm{CN}$ & & & & \\
\hline Dividend payout ratio & & & & & - & BKS & - & BKS & & & & \\
\hline Total equity risk & & & & & & & & & & & & \\
\hline Abnormal returns & & & & & & & & & & & + & ОВ.ВН \\
\hline Growth ${ }^{14}$ & & & & & + & BKS & & & - & SW & + & $\mathrm{OB}$ \\
\hline Share Price & & & & & & & - & $\mathrm{CN}$ & & & & \\
\hline
\end{tabular}

Sources: AB: Alford and Boatsman (1995); BKS: Beaver. Kettler. and Scholes (1970); Bhushan (1989); BH: Brennan and Hughes (1991); Banz: Banz (1981); CN: Cheung and Ng (1992); EYR: Ederington, Yawitz, and Roberts. 1987. Hamada: Hamada (1972); KU: Kaplan and Urwitz (1979); OB: O'Brien and Bhushan (1990); Ogden: Ogden (1987); SW: Smith and Watts (1992).

${ }^{13}$ Many papers propose that analyst following is related to information asymmetry. We use bid-ask spread as a measure of information asymmetry.

${ }^{14}$ For betas and dividend payout ratios, we use market-to-book ratios and separately sales growth as proxies for growth. For analyst following. consistent with the methodology of $O$ 'Brien and Bhushan (1990), growth is the net entry of firms into the sample firm's industry over the five-year period prior to the sample year. 
Table 9

Means of annual regressions of proxies for the cost of accessing capital markets on cash flow and earnings volatility.

Means of annual regressions of proxies for the costs of accessing capital markets on cash flow volatility and earnings volatility. Proxies for these costs are defined in lable 6 . LOCF ( $\mathrm{LOAL}$ ) and $\mathrm{HICF}$ (HIAL) are indicator variables equal to one if a firm is in the lowest or highest three decile rankings, respectively, based on the level of its industry-adjusted cash flow (accounting earnings). Cash flow after investment is operating cash flow - net capital expenditures including R\&D and advertising. Operating income is sales - cost of goods sold - selling. general and administrative expenses (excluding R\&D and advertising) - depreciation and amortization. Net cash flow is operating cash flow - net capital expenditures (including R\&D and advertising) aftertax interest charges. Net income is Compustat data item 69 . For each equation. means of the eight annual least squares values for each coefficient $\left(\bar{\alpha}_{i t}\right)$ are presented. z-statistics to test the hypothesis that $E(\bar{\alpha})$ are shown in parentheses. Influential observations in the annual estimations are downweighted by the method of Welsch (1980). Coefficient estimates on control variables included in the regressions (summarized in lable 8) are not presented.

\begin{tabular}{|c|c|c|c|c|c|c|c|c|c|c|c|c|}
\hline \multirow{2}{*}{$\begin{array}{l}\text { Dependent } \\
\text { Variable: }\end{array}$} & \multirow[b]{2}{*}{ Intcpt. } & \multicolumn{2}{|c|}{ Intercept $^{*}$} & \multirow[t]{2}{*}{$\mathrm{CVCF}$} & \multicolumn{2}{|c|}{$\mathrm{CVCF}$} & \multicolumn{2}{|c|}{ Intercept* } & \multirow[t]{2}{*}{ CVINC } & \multicolumn{2}{|c|}{ CVINC } & \multirow[b]{2}{*}{ Range of Adj. $R^{2} s$} \\
\hline & & $\mathrm{LOCH}$ & $\mathrm{HICF}$ & & $\mathrm{LOCF}$ & $\mathrm{HICF}$ & LOAE & HIAE & & LOAE & HIAE & \\
\hline \multicolumn{13}{|c|}{ Costs of accessing debt markcts: Cash flow is defined as cash flow after investment (CFAI). Earnings is defined as operating income (OPINC) } \\
\hline $\begin{array}{l}\text { S\&P bond } \\
\text { rating }\end{array}$ & $\begin{array}{c}-0.2856 \\
(-1.444)\end{array}$ & $\begin{array}{c}0.3482 \\
(2.958)\end{array}$ & $\begin{array}{c}0.5029 \\
(2.130)\end{array}$ & $\begin{array}{c}0.0341 \\
(2.952)\end{array}$ & $\begin{array}{l}-0.0287 \\
(-1.937)\end{array}$ & $\begin{array}{c}0.1440 \\
(1.169)\end{array}$ & $\begin{array}{c}1.6975 \\
(9.347)\end{array}$ & $\begin{array}{l}-0.0617 \\
(-0.244)\end{array}$ & $\begin{array}{c}0.0415 \\
(0.381)\end{array}$ & $\begin{array}{l}-0.1003 \\
(-0.936)\end{array}$ & $\begin{array}{c}0.6252 \\
(1.733)\end{array}$ & $54.45 \%$ \\
\hline $\begin{array}{l}\text { Yield-to- } \\
\text { maturity }\end{array}$ & $\begin{array}{c}0.2496 \\
(0.604)\end{array}$ & $\begin{array}{c}0.4848 \\
(0.825)\end{array}$ & $\begin{array}{l}0.04293 \\
(0.715)\end{array}$ & $\begin{array}{r}0.0697 \\
(1.251)\end{array}$ & $\begin{array}{l}-0.0595 \\
(-0.962)\end{array}$ & $\begin{array}{l}-0.0626 \\
(-0.265)\end{array}$ & $\begin{array}{l}-0.1721 \\
(-0.327)\end{array}$ & $\begin{array}{l}0.1348 \\
(0.315)\end{array}$ & $\begin{array}{c}0.3780 \\
(1.785)\end{array}$ & $\begin{array}{l}-0.4037 \\
(-1.889)\end{array}$ & $\begin{array}{c}0.1901 \\
(0.307)\end{array}$ & $33.88 \%$ \\
\hline \multicolumn{13}{|c|}{ Costs of accessing cquity markets: Cash flow is defined as net cash flow (NETCF). Earnings is defined as net income (NETINC) } \\
\hline $\begin{array}{l}\text { Stock } \\
\text { market beta }\end{array}$ & $\begin{array}{c}0.2402 \\
(6.880)\end{array}$ & $\begin{array}{c}0.0900 \\
(2.807)\end{array}$ & $\begin{array}{l}-0.0418 \\
(-1.643)\end{array}$ & $\begin{array}{c}0.0030 \\
(1.538)\end{array}$ & $\begin{array}{l}-0.0054 \\
(-1.745)\end{array}$ & $\begin{array}{c}0.0047 \\
(0.859)\end{array}$ & $\begin{array}{c}0.0855 \\
(1.895)\end{array}$ & $\begin{array}{c}-0.0489 \\
(-1.898)\end{array}$ & $\begin{array}{c}0.0149 \\
(3.536)\end{array}$ & $\begin{array}{l}-0.0170 \\
(-2.797)\end{array}$ & $\begin{array}{l}-0.0073 \\
(-0.721)\end{array}$ & $19.64 \%$ \\
\hline $\begin{array}{l}\text { Std dev of } \\
\text { returns }\end{array}$ & $\begin{array}{c}0.0014 \\
(1.311)\end{array}$ & $\begin{array}{c}0.0007 \\
(2.745)\end{array}$ & $\begin{array}{l}0.0007 \\
(1.817)\end{array}$ & $\begin{array}{l}0.00003 \\
(3.296)\end{array}$ & $\begin{array}{l}-0.0001 \\
(-2.404)\end{array}$ & $\begin{array}{c}0.0001 \\
(1.192)\end{array}$ & $\begin{array}{c}0.0026 \\
(7.588)\end{array}$ & $\begin{array}{l}0.0002 \\
(1.138)\end{array}$ & $\begin{array}{c}0.0002 \\
(2.992)\end{array}$ & $\begin{array}{l}-0.0003 \\
(-4.172)\end{array}$ & $\begin{array}{c}0.0001 \\
(0.457)\end{array}$ & $63.92 \%$ \\
\hline $\begin{array}{l}\text { Analyst } \\
\text { following }\end{array}$ & $\begin{array}{l}1.0133 \\
(2.200)\end{array}$ & $\begin{array}{l}-0.5638 \\
(-2.202)\end{array}$ & $\begin{array}{c}0.5641 \\
(2.048)\end{array}$ & $\begin{array}{l}-0.0357 \\
(-3.578)\end{array}$ & $\begin{array}{c}0.0368 \\
(1.901)\end{array}$ & $\begin{array}{c}0.2747 \\
(6.687)\end{array}$ & $\begin{array}{l}-0.4434 \\
(-2.038)\end{array}$ & $\begin{array}{l}1.1596 \\
(7.815)\end{array}$ & $\begin{array}{l}-0.0653 \\
(-0.124)\end{array}$ & $\begin{array}{c}0.0686 \\
(0.081)\end{array}$ & $\begin{array}{c}0.2206 \\
(1.402)\end{array}$ & $62.74 \%$ \\
\hline $\begin{array}{l}\text { Dividend } \\
\text { payout ratio }\end{array}$ & $\begin{array}{r}0.1807 \\
(17.251)\end{array}$ & $\begin{array}{l}-0.0693 \\
(-5.740)\end{array}$ & $\begin{array}{c}0.0420 \\
(5.299)\end{array}$ & $\begin{array}{l}-0.0008 \\
(-1.464)\end{array}$ & $\begin{array}{l}-0.00002 \\
(0.104)\end{array}$ & $\begin{array}{l}-0.0040 \\
(-1.692)\end{array}$ & $\begin{array}{l}-0.1122 \\
(-20.515)\end{array}$ & $\begin{array}{l}-0.0131 \\
(-1.253)\end{array}$ & $\begin{array}{l}-0.0061 \\
(-3.755)\end{array}$ & $\begin{array}{c}0.0060 \\
(3.810)\end{array}$ & $\begin{array}{l}-0.0026 \\
(-0.315)\end{array}$ & $19.21 \%$ \\
\hline \multicolumn{13}{|c|}{ Costs of accessing dcbt and cquity markets: Cash flow is defined as cash flow after investment (CFAI). Earnings is dcfined as operating income (OPINC) } \\
\hline WACC & $\begin{array}{c}0.0445 \\
(0.259)\end{array}$ & $\begin{array}{c}0.3360 \\
(1.248)\end{array}$ & $\begin{array}{c}0.2512 \\
(1.008)\end{array}$ & $\begin{array}{c}0.0266 \\
(1.140)\end{array}$ & $\begin{array}{l}-0.0311 \\
(-1.136)\end{array}$ & $\begin{array}{c}0.1345 \\
(1.423)\end{array}$ & $\begin{array}{l}-0.0011 \\
(-0.005)\end{array}$ & $\begin{array}{l}-0.1449 \\
(-0.798)\end{array}$ & $\begin{array}{c}0.0219 \\
(0.223)\end{array}$ & $\begin{array}{l}-0.0458 \\
(-0.452)\end{array}$ & $\begin{array}{l}-0.0869 \\
(-0.308)\end{array}$ & $58.52 \%$ \\
\hline
\end{tabular}

